Article

\title{
Chemical Defense Mechanisms and Ecological Implications of Indo-Pacific Holothurians
}

\author{
Elham Kamyab ${ }^{1, *(\mathbb{D})}$, Sven Rohde ${ }^{1}(\mathbb{D})$, Matthias Y. Kellermann ${ }^{1}$ and Peter J. Schupp ${ }^{1,2, *(\mathbb{D})}$ \\ 1 Institute for Chemistry and Biology of the Marine Environment (ICBM), Carl-von-Ossietzky \\ University Oldenburg, Schleusenstrasse 1, 26382 Wilhelmshaven, Germany; sven.rohde@uol.de (S.R.); \\ matthias.kellermann@uni-oldenburg.de (M.Y.K.) \\ 2 Helmholtz Institute for Functional Marine Biodiversity, University of Oldenburg, \\ Ammerländer Heerstrasse 231, D-26129 Oldenburg, Germany \\ * Correspondence: elham.kamyab@uol.de (E.K.); peter.schupp@uni-oldenburg.de (P.J.S.); \\ Tel.: +49-4421-944-100 (P.J.S.)
}

Academic Editor: David Popovich

check for Received: 14 August 2020; Accepted: 13 October 2020; Published: 19 October 2020

updates

\begin{abstract}
Sea cucumbers are slow-moving organisms that use morphological, but also a diverse combination of chemical defenses to improve their overall fitness and chances of survival. Since chemical defense compounds are also of great pharmaceutical interest, we pinpoint the importance of biological screenings that are a relatively fast, informative and inexpensive way to identify the most bioactive organisms prior to further costly and elaborate pharmacological screenings. In this study, we investigated the presence and absence of chemical defenses of 14 different sea cucumber species from three families (Holothuriidae, Stichopodidae and Synaptidae) against ecological factors such as predation and pathogenic attacks. We used the different sea cucumber crude extracts as well as purified fractions and pure saponin compounds in a portfolio of ecological activity tests including fish feeding assays, cytotoxicity tests and antimicrobial assays against environmental pathogenic and non-pathogenic bacteria. Furthermore, we quantified and correlated the concentrations of sea cucumber characteristic saponin compounds as effective chemical defensive compounds in all 14 crude extracts by using the vanillin-sulfuric acid test. The initial results revealed that among all tested sea cucumber species that were defended against at least one ecological threat (predation and/or bacterial attack), Bohadschia argus, Stichopus choloronotus and Holothuria fuscopunctata were the three most promising bioactive sea cucumber species. Therefore, following further fractionation and purification attempts, we also tested saponin-containing butanol fractions of the latter, as well as two purified saponin species from B. argus. We could demonstrate that both, the amount of saponin compounds and their structure likely play a significant role in the chemical defense strategy of the sea cucumbers. Our study concludes that the chemical and morphological defense mechanisms (and combinations thereof) differ among the ecological strategies of the investigated holothurian species in order to increase their general fitness and level of survival. Finally, our observations and experiments on the chemical ecology of marine organisms can not only lead to a better understanding of their ecology and environmental roles but also can help in the better selection of bioactive organisms/compounds for the discovery of novel, pharmacologically active secondary metabolites in the near future.
\end{abstract}

Keywords: echinoderms; chemical ecology; cuvierian tubule; antiinfectivity assays; palatability; cytotoxicity; saponins 


\section{Introduction}

Marine organisms hold a great variety of structurally diverse bioactive compounds (BCs) with often multiple biological activities [1,2]. Among marine organisms, echinoderms are excellent models for studying chemical defense strategies and their implications in marine natural products research. They, as potential bioremediators of the coastal ecosystem, belong to the deuterostome superphylum and share their evolutionary history with hemichordates and chordates [3,4], which make their regulatory mechanisms and their physiology rather similar to vertebrates. For example, studies of their hormone and regulatory factors (i.e., peptides, glycoproteins and steroids) showed that they can synthesize vertebrate-type steroids and hormonal factors that regulate their reproductive, growth, regeneration and developmental processes [5-7].

Holothuroidea are one of the most abundant and dominant classes of echinoderms, with more than 1400 described species inhabiting almost all marine habitats including abyssal plains, although they are constantly under predaceous pressure from fish, sea stars, crustaceans and gastropods [8-10]. They are slow moving, mostly deposit-feeding organisms, which play an important role in nutrient recycling through their benthic bioturbation activities and reworking sediments, thereby incorporating particulate organic matter [11,12]. Furthermore, their ability to convert organic waste to inorganic nitrogenous and phosphorous-rich compounds not only increases the productivity of marine ecosystems, but it also affects the alkalinity of their habitat [13]. Therefore, their high local buffer capacities assist marine environments against ocean acidification [14-16]. Some sea cucumber species are economically highly valuable as both a traditional delicacy for people, as well as medicine (i.e., wound healing, eczema, arthritis, hypertension and impotence [17]).

According to the Optimal Defense Theory (ODT), the consumed energy of organisms is allocated to different physiological processes in a way that maximizes fitness with minimum costs [18-20]. In other words, costs, benefits and probability of attack are the three main factors that influence the defensive pattern of an organism [21]. Therefore, based on ecological, behavioral and physiological differences in various orders of sea cucumbers, a variety of defensive strategies have evolved as protection against predatory pressures. For example, Cuvierian Tubules (CT) are a known defensive organ in Holothurians that differs among species in terms of presence/absence, its shape and functionality. CTs are not sticky (lobulated CT) in some sea cucumbers (i.e., Holothuria hilla, Holothuria whitmeai, Actinopyga echinitis and Actinopyga mauritiana) and cannot be elongated for defense purposes against predators. In contrast, sea cucumber such as the genus Bohadschia and Holothuria forskali have sticky, active CTs (smooth CT) that are effective against predators (see Figure 1, [22,23]). The presence or functionality of CTs also explains partially the evolutionary distance of some families [22,24]. Besides CTs, sea cucumbers have developed other defensive strategies such as excretion of toxic compounds, expelling the internal organs (also called evisceration, e.g., in Holothuria atra; [25,26], autotomy (e.g., in Synapta maculata; [27]) or morphological defenses such as possession of spikes (e.g., in Thelenota ananas, Bohadschia; [25]) or thickening of the body wall (e.g., in Holothuria edulis; [28]). In addition, there are behavioral adaptations such as cryptic behavior (e.g., in Holothuria hilla; [29]) or escape behavior such as swimming (e.g., in Synaptids and deep-water species; [28,30-32]). The above described morphological and behavioral defense mechanisms are often combined with chemical defenses via production of bioactive molecules [33]. These molecules have been shown to act not only as antipredatory defense but also as potent antimicrobial and antifungal compounds [34-40] that can control associated microbial communities or prevent pathogenic attacks $[37,41]$. Among the wide spectrum of bioactive compounds present in several orders of sea cucumbers (i.e., Holothuroidea, Echinodermata; [34,42,43]), triterpene glycosides (or saponins) are a potent and prominent example for such bioactive defense molecules.

In this study, we investigated the crude extracts of 14 tropical sea cucumber species from three families (Holothuriidae, Stichopodidae and Synaptidae (Figure 1) collected in Guam, Western Pacific for their possible chemical defense mechanisms. These crude extracts were evaluated by biological activity tests including fish feeding assays, cytotoxicity tests as well as antimicrobial assays 
against environmental pathogenic and non-pathogenic bacteria. The most active crude extracts were further fractionated with a focus on saponin content and individual saponin compounds to identify the most likely secondary metabolite responsible for the here observed biological activities. Finally, we investigated possible relationships between sea cucumber bioactivities and their defense strategies, which may assist us in identifying the most promising candidates for future pharmacological-based studies.

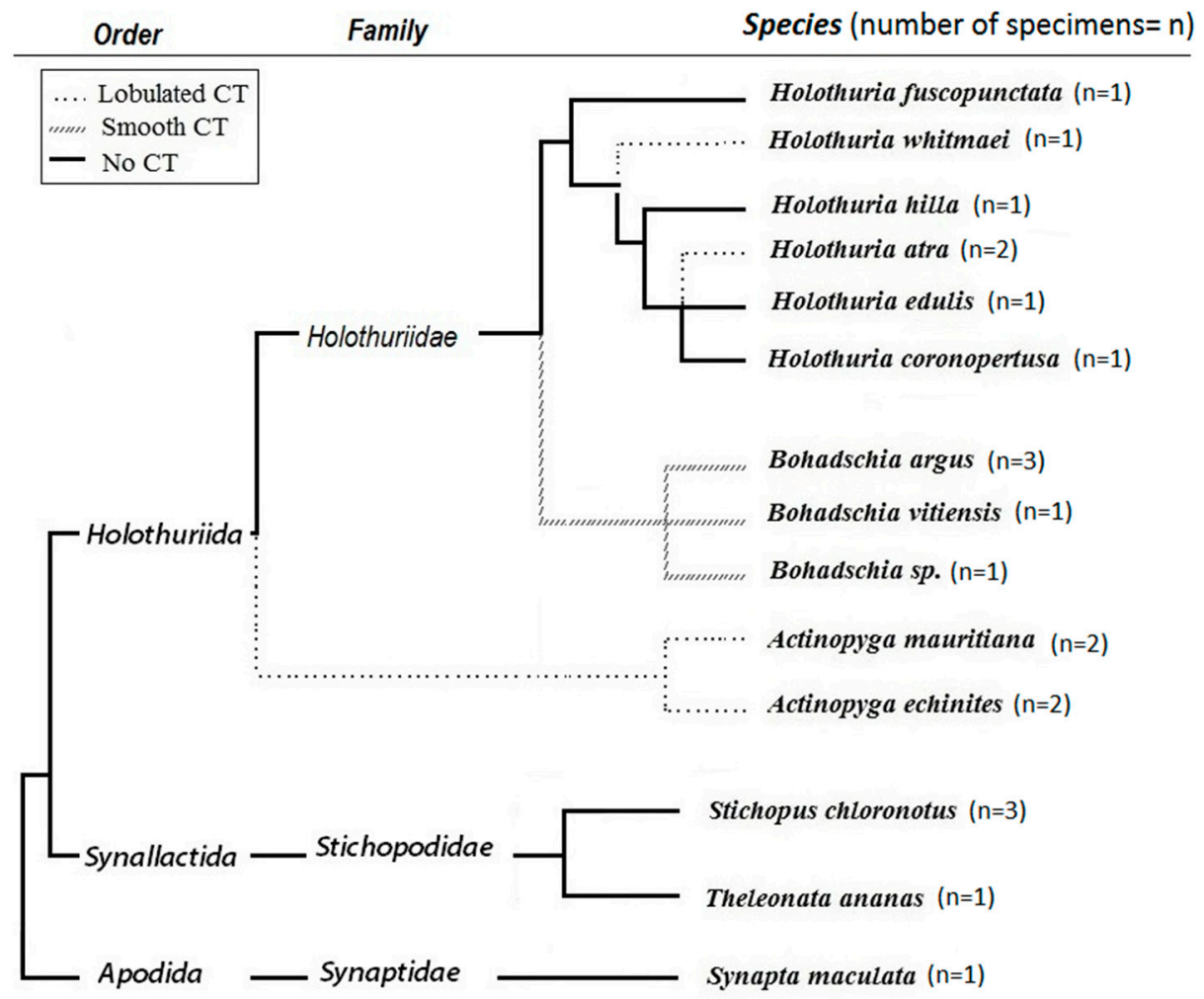

Figure 1. Phylogeny tree and presence/absence of Cuvierian Tubules (CTs) in studied sea cucumbers ( $\mathrm{n}=$ number of tested specimens; adapted from [32,44-46]).

\section{Results}

\subsection{Evaluation of the Crude Extracts from 14 Different Sea Cucumber Species}

\subsubsection{Feeding Assay (FA)}

The assays showed that all but three (H. coronopertusa, H. hilla and S. maculata) of the 14 sea cucumber crude extracts deterred significantly the feeding of the omnivorous puffer fish, Canthigaster solandri. Among the active crude extracts, all three Bohadschia species, two species of Holothuria (H. edulis, H. fuscopunctata) and Actinpyga mauritiana deterred nearly $100 \%$ feeding by the puffer fish (cf. Figure 2).

\subsubsection{Cytotoxicity Test: Brine Shrimp Assay}

Cytotoxicity of the crude extracts was clearly concentration-dependent, with the highest mortality rates $(\mathrm{M})$ at $1000 \mu \mathrm{g} \mathrm{mL}-1$. Hence, after $24 \mathrm{~h}$, extracts of $B$. argus $(\mathrm{M}=98.4 \% \pm \mathrm{SD}=7.7)$, H. edulis $(66.7 \% \pm 13.3)$, S. chloronotus $(53.3 \% \pm 25.4)$ and $H$. coronopertusa $(53.3 \% \pm 11.5)$ revealed the highest cytotoxicity. Meanwhile, after $48 \mathrm{~h}$, ten out of the total fourteen crude extracts caused more than $50 \%$ mortality, especially at high concentrations $\left(1000 \mu \mathrm{g} \mathrm{mL}{ }^{-1}\right.$, Figure 3$)$. Among all, the highest mortality rate was observed in $H$. edulis $(100 \% \pm 0.00)$, B. argus $(96.7 \% \pm 3.9)$, H. fuscopunctata $(94.4 \% \pm 6.9)$ and $S$. chloronotus $(94 \% \pm 4.9)$, respectively. 


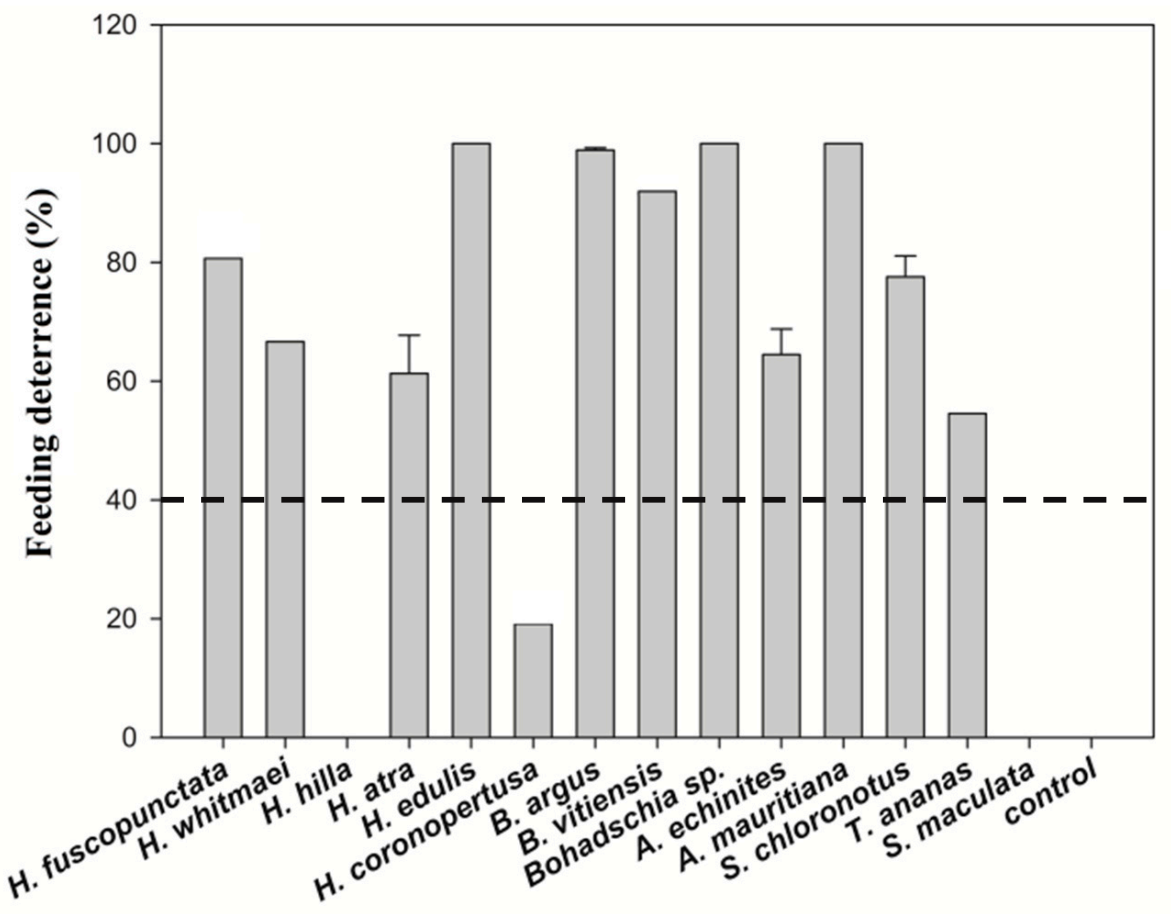

Figure 2. Percent feeding deterrent activity of sea cucumber crude extracts. The line at $40 \%$ indicates significant deterrence ( $p<0.05$, Fisher's exact test, 1-tailed). Results express average values + standard error for the four replicated sea cucumber species (i.e., H. atra, A. echinites, S. chloronotus and B. argus).

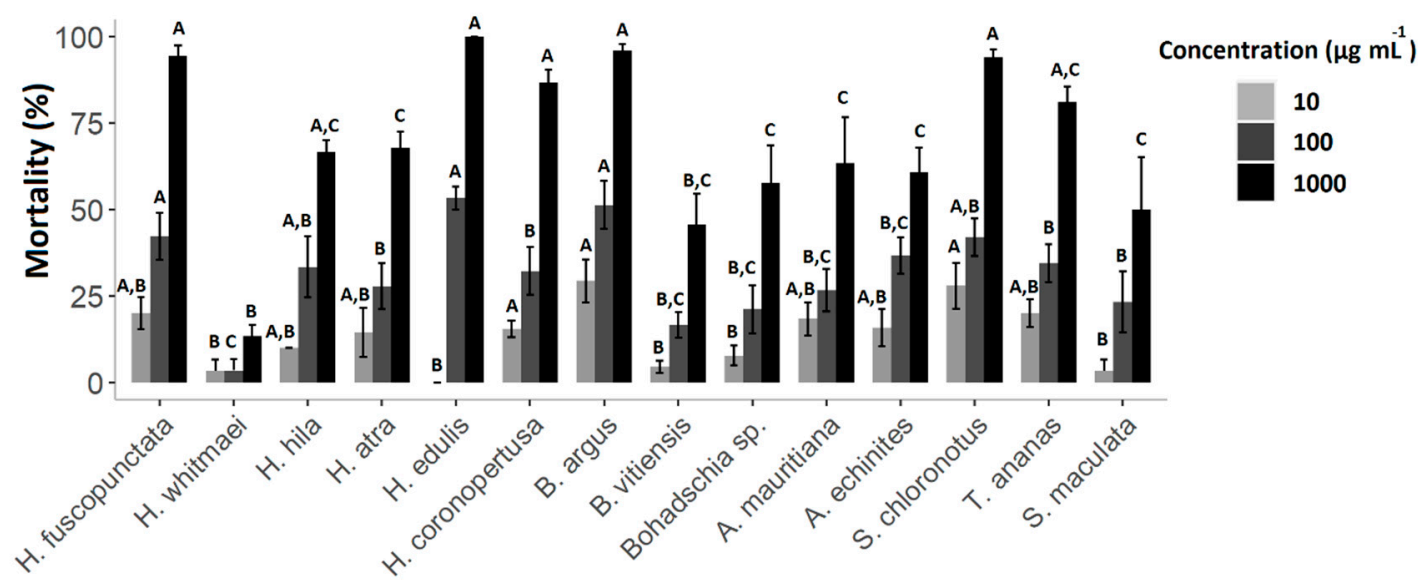

Figure 3. Percentages of brine shrimp mortality following exposure to sea cucumber crude extracts at a concentrations of 10,100 and $1000 \mu \mathrm{g} \mathrm{mL}^{-1}$ after $48 \mathrm{~h}$. Results express average values \pm standard deviation. $\mathrm{A}, \mathrm{B}$ and $\mathrm{C}$ indicate significant differences between species at each concentration (Kruskal-Wallis post-hoc test, $p<0.05)$.

Based on the Clarkson toxicity index, the toxicity level is classified into several levels of highly toxic $\left(\mathrm{LC}_{50}<100 \mu \mathrm{g} \mathrm{mL}^{-1}\right)$, medium $\left(500<\mathrm{LC}_{50}<100 \mu \mathrm{g} \mathrm{mL}^{-1}\right)$, low toxic $\left(500<\mathrm{LC}_{50}<1000 \mu \mathrm{g} \mathrm{mL}^{-1}\right)$ and non-toxic $\left(\mathrm{LC}_{50}>1000 \mu \mathrm{g} \mathrm{mL} \mathrm{L}^{-1} ;\right.$ [47-49]). In general, the results showed that extracts had different toxicities depending on how long the assay was conducted for. After $24 \mathrm{~h}, 71.4 \%$ of the tested crude extracts were non-toxic, and only the extracts from three species (i.e., H. edulis, B. argus and Bohadschia sp.) showed medium toxicity (results not shown). After $48 \mathrm{~h}$ incubation, only $14.3 \%$ of organic extracts showed no toxicity, $35.7 \%$ had low toxicity, and over half of the tested extracts (57.1\%) displayed medium toxicity. Extracts of B. argus, S. chloronotus and A. mauritiana showed the highest cytotoxicity levels with $\mathrm{LC}_{50}$ of $181.4 \pm 2.1,234.7 \pm 1.0$ and $241.7 \pm 0.9 \mu \mathrm{g} \mathrm{mL} \mathrm{m}^{-1}$, respectively (Figure 4). 


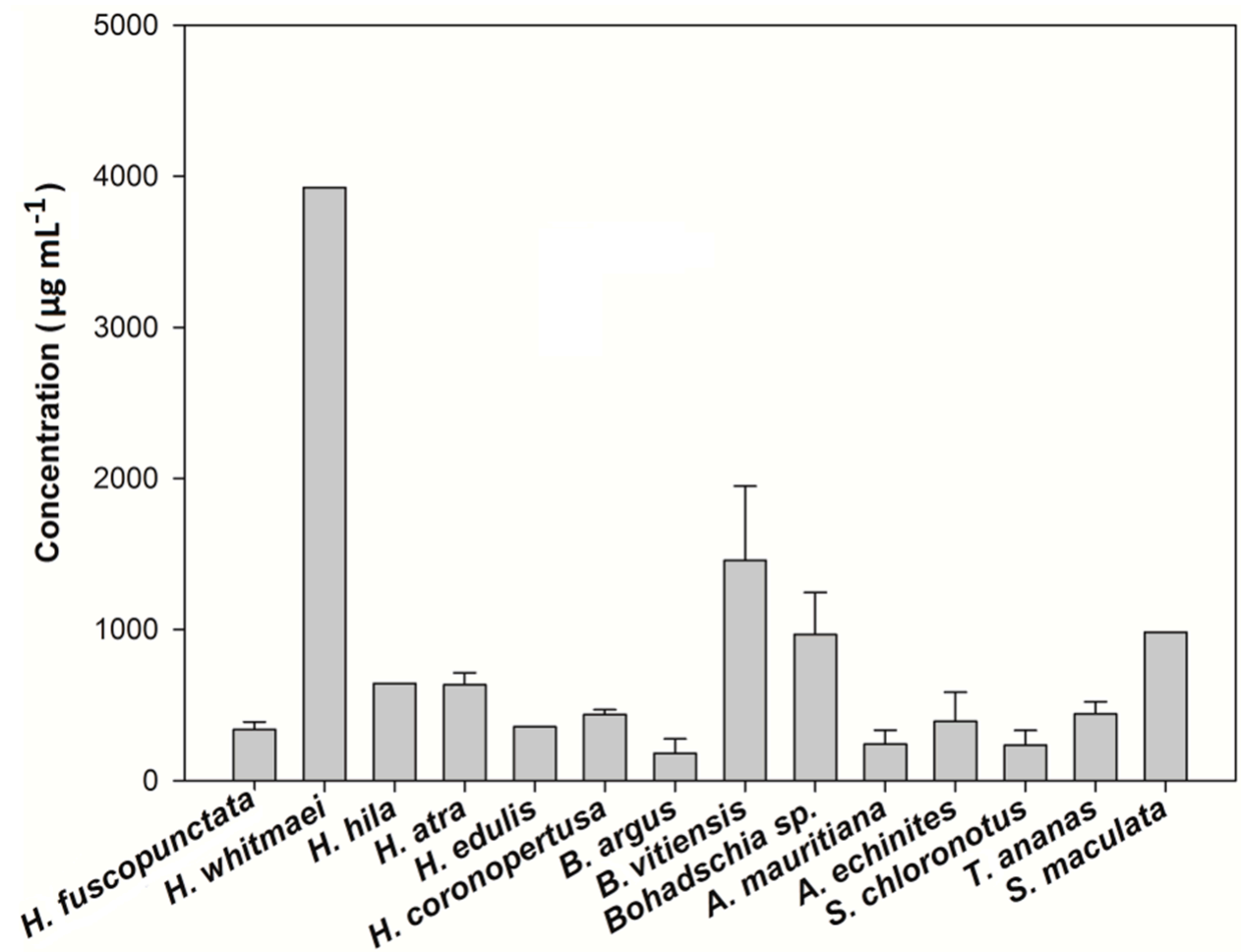

Figure 4. Calculated $\mathrm{LC}_{50}$ concentrations from the brine shrimp mortality assay for the 14 different sea cucumber crude extracts after $48 \mathrm{~h}$. Results express average values + standard error.

\subsubsection{Antimicrobial Testing: Agar Diffusion Assay (ADA)}

Antimicrobial activities of the sea cucumber crude extracts against 15 strains of pathogenic and non-pathogenic environmental bacteria were assessed after $24 \mathrm{~h}$ of incubation. Crude extracts showed inhibition of most of the pathogenic bacteria (Figure 5). Antibacterial activity is displayed as inhibition potential, which is the inhibition zone per strain (in $\mathrm{mm}$ ) of bacterial strains that were inhibited. Extracts of $H$. fuscopunctata, $H$. coronopertusa, B. argus, B. vitiensis, A. mauritiana, S. chloronotus and T. ananas showed pronounced inhibition (expressed as more than $50 \%$ inhibition potential) of the tested pathogenic and two non-pathogenic bacteria (i.e., Acinetobacter calccoaceticus, and Pseudovibrio sp.; Figure 5). Although all extracts showed medium activities against the two pathogenic bacteria Aurantimonas coralicida and Pantoea sp., four crude extracts (from A. echinites, H. coronopertusa, H. whitmaei and $H$. hilla) had very high antibacterial capacities $(<75 \%$ inhibition potential) against some pathogenic bacteria (Table S2, Figure 5).

\subsubsection{Total Saponin Concentration}

The total saponin concentration of the crude extracts was assessed using the vanillin-sulfuric acid colorimetric assay (Table 1). The results showed that both species of the genus Actinopyga had significantly higher saponin concentration than most of the studied species (Kruskal-Wallis test; $p<0.05)$. That is, A. echinites and A. mauritiana had values of $2.11 \pm 0.1 \mathrm{SE}$ and $1.89 \pm 0.19 \mathrm{mg} \mathrm{mL}^{-1}$, respectively, the highest absolute concentrations, followed by $S$. chloronotus $\left(1.29 \mathrm{mg} \mathrm{mL}^{-1} \pm 0.01\right)$, T. ananas $\left(1.15 \mathrm{mg} \mathrm{mL}^{-1} \pm 0.01\right)$ and B. argus $\left(1.13 \mathrm{mg} \mathrm{mL}^{-1} \pm 0.01\right)$. H. atra and H. whitmaei had the lowest concentration values with $0.46 \pm 0.08$ and $0.49 \pm 0.07 \mathrm{mg} \mathrm{mL}^{-1}$, respectively (cf. Figures 6 and 7). 
Table 1. Summary of all biological activities tested against the 14 sea cucumber crude extracts (cf. Figure 7 and Figure S1).

\begin{tabular}{|c|c|c|c|c|c|c|c|c|c|c|c|c|c|c|c|}
\hline \multirow{5}{*}{$\begin{array}{l}\text { Conducted } \\
\text { Bioassays }\end{array}$} & \multirow{5}{*}{ Indicator of } & \multicolumn{14}{|c|}{ Class: Holothuroidea } \\
\hline & & \multicolumn{11}{|c|}{ Order: Holothuriida } & \multirow{3}{*}{\multicolumn{2}{|c|}{$\begin{array}{l}\text { Synallactida } \\
\text { Stichopodiidae }\end{array}$}} & \multirow{4}{*}{$\begin{array}{c}\text { Apodida } \\
\text { Synaptidae } \\
\begin{array}{c}\text { S. } \\
\text { maculata }\end{array}\end{array}$} \\
\hline & & \multicolumn{11}{|c|}{ Family: Holothuriidae } & & & \\
\hline & & \multicolumn{6}{|c|}{ Holothuria } & \multicolumn{3}{|c|}{ Bohadschia } & \multicolumn{2}{|c|}{ Actinopyga } & & & \\
\hline & & $\begin{array}{c}\text { H. } \\
\text { fuscopunctata }\end{array}$ & $\begin{array}{c}\text { H. } \\
\text { whitmaei }\end{array}$ & H. hilla & H. atra & H. edulis & $\begin{array}{c}H . \\
\text { coronopertusa }\end{array}$ & B. argus & $\begin{array}{c}B . \\
\text { vitiensis }\end{array}$ & Bohadshia sp. & $\begin{array}{c}\text { A. } \\
\text { mauritiana }\end{array}$ & $\begin{array}{c}\text { A. } \\
\text { echinites }\end{array}$ & $\begin{array}{c}S . \\
\text { chloronotus }\end{array}$ & T. ananas & \\
\hline Feeding Assay & Unpalatability & deterrent & deterrent & $\begin{array}{c}\text { non- } \\
\text { deterrent }\end{array}$ & deterrent & deterrent & $\begin{array}{c}\text { non- } \\
\text { deterrent }\end{array}$ & deterrent & deterrent & deterrent & deterrent & deterrent & deterrent & deterrent & $\begin{array}{c}\text { non- } \\
\text { deterrent }\end{array}$ \\
\hline \multirow{2}{*}{ Cytotoxicity } & $\mathrm{LC}_{50}-24 \mathrm{~h}$ & non-toxic & $\begin{array}{l}\text { non- } \\
\text { toxic }\end{array}$ & non-toxic & $\begin{array}{l}\text { non- } \\
\text { toxic }\end{array}$ & medium & non-toxic & medium & $\begin{array}{l}\text { non- } \\
\text { toxic }\end{array}$ & medium & non-toxic & $\begin{array}{l}\text { non- } \\
\text { toxic }\end{array}$ & non-toxic & non-toxic & non-toxic \\
\hline & $\mathrm{LC}_{50}-48 \mathrm{~h}$ & medium & non-toxic & low & Low & medium & medium & medium* & non-toxic & low & medium * & low & medium * & medium & Low \\
\hline \multirow{2}{*}{$\begin{array}{c}\text { Agar } \\
\text { Diffusion Test } \\
\text { (\% Inhibition) }\end{array}$} & Pathogen & 77.8 & 33.3 & 22.2 & 22.2 & 44.5 & 77.8 & 55.6 & 55.6 & 33.3 & 55.6 & 22.2 & 88.9 & 77.8 & 33.3 \\
\hline & $\begin{array}{c}\text { Non- } \\
\text { Pathogen }\end{array}$ & 33.3 & 0 & 0 & 0 & 0 & 33.3 & 16.7 & 16.7 & 16.7 & 0 & 0 & 33.3 & 33.3 & 0 \\
\hline \multirow{2}{*}{$\begin{array}{c}\text { Defense } \\
\text { Mechanism }\end{array}$} & CT & No CT & LCT & LCT & No CT, & No CT & NR & SCT & SCT & SCT & LCT & LCT & No CT & No CT & No CT \\
\hline & Behavior & Semi-Ex & Semi-Ex & $\mathrm{EV}, \mathrm{CB}$ & $\mathrm{EV}, \mathrm{Ex}$ & Semi-Ex & Dw dweller & Ex & Ex & Ex & Ex & Ex & Shedding, Ex & Shedding, Ex & $\mathrm{CB}$ \\
\hline \multicolumn{2}{|c|}{$\begin{array}{l}\text { Total Saponin Concentration } \\
\qquad\left(\mathrm{mg} \mathrm{mL}^{-1}\right)\end{array}$} & $0.78 \pm 0.1$ & $0.49 \pm 0.1$ & $0.98 \pm 0.1$ & $0.46 \pm 0.1$ & $0.97 \pm 0.1$ & $0.79 \pm 0.0$ & $1.13 \pm 0.0$ & $0.83 \pm 0.1$ & $0.86 \pm 0.0$ & $1.89 \pm 0.2$ & $2.11 \pm 0.1$ & $1.29 \pm 0.0$ & $1.15 \pm 0.09$ & $0.73 \pm 0.07$ \\
\hline \multicolumn{2}{|c|}{$\begin{array}{l}\text { Main Type of Sapoinin } \\
\text { (Sulfated/Non-Sulfated) }\end{array}$} & non-sulfated & sulfated & sulfated & sulfated & sulfated & NR & non-sulfate & Anon-sulfated & non-sulfated & sulfated & sulfated & non-sulfated & non-sulfated & NR \\
\hline
\end{tabular}

CT: Cuvierien Tubules; LCT: Lobulated CT; SCT: Smooth CT; CB: Cryptic Behaviour; Ex: Exposed; Ev: Evisceration; Dw: Deep water dweller; NR: Not Reported; FA: Fish feeding assay:

deterrent, non-deterrent; ADA: Agar diffusion assay: against environmental pathogenic and non-pathogenic bacteria; ${ }^{*}=100<\mathrm{LC}_{50}<200$. 


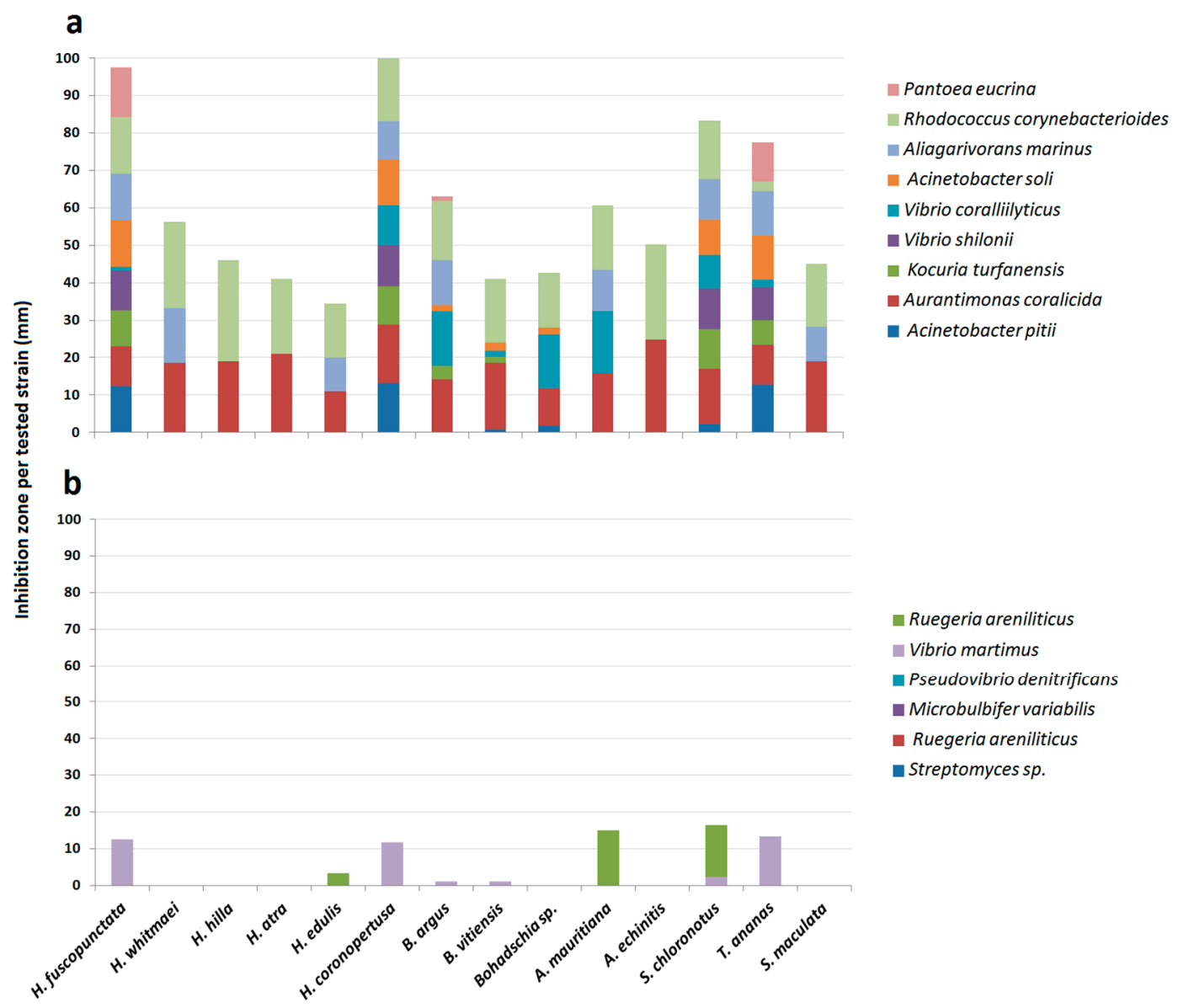

Figure 5. Total antibacterial activities of sea cucumber crude extracts against pathogenic (a) and non-pathogenic (b) environmental bacteria.

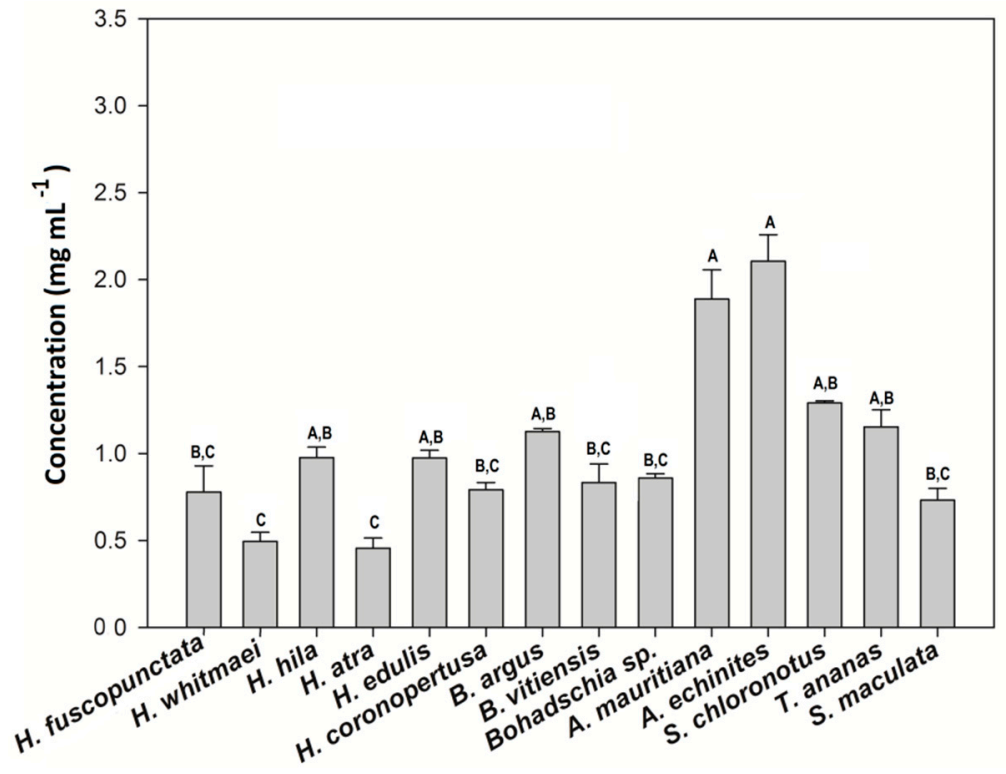

Figure 6. Saponin concentration of the 14 tested sea cucumber crude extracts. Results express average values + standard error. (A-C) indicate significant differences between sea cucumber crude extracts. The Kruskal-Wallis post-hoc method for multiple comparisons was applied $(p<0.05)$. 


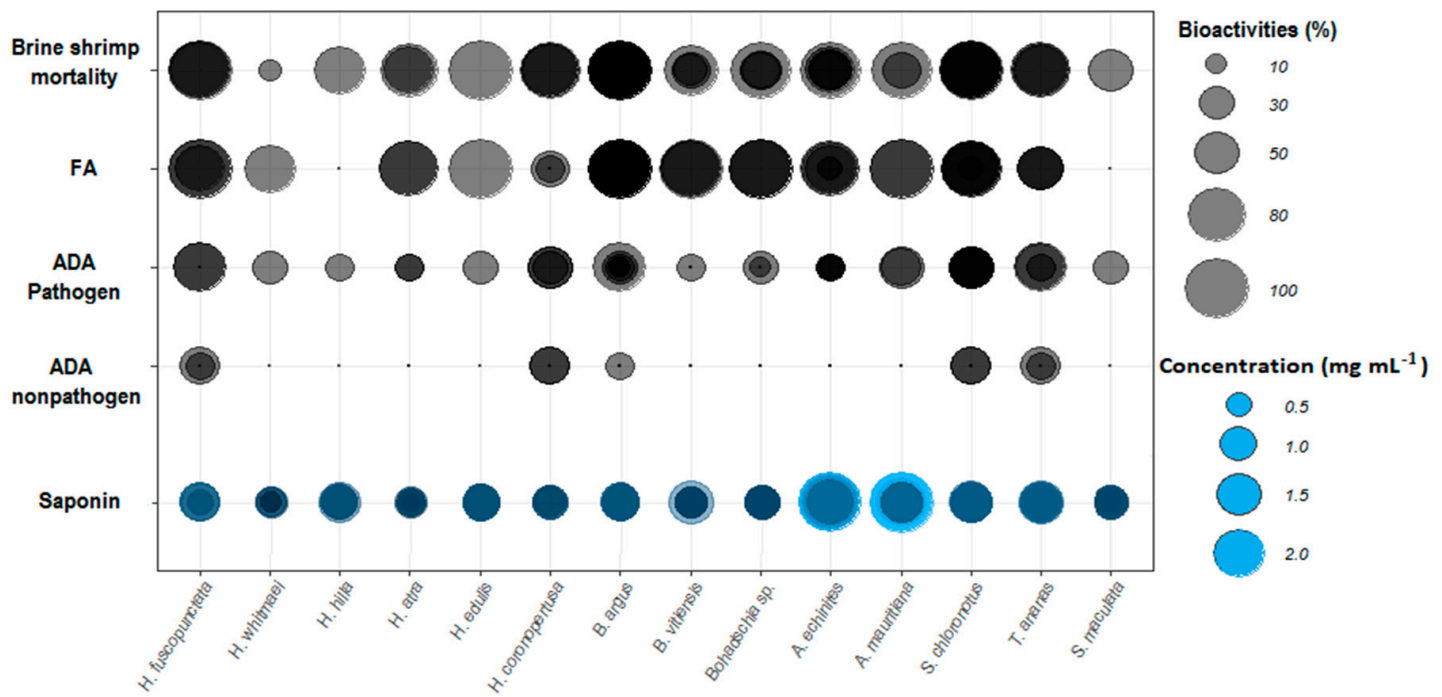

Figure 7. Overall biological activities of the tested sea cucumber crude extracts. Sizes of bubble plots represent the percentage of each bioactivity for the four different bioassays. Color intensities represent the overlap of the replicates (duplicates; cf. Figure 1). Abbreviations: FA = fish feeding assay (\% deterrence), $\mathrm{ADA}=$ agar diffusion assay against environmental pathogenic and non-pathogenic bacteria.

\subsection{Evaluation of Saponin Containing Fractions and Two Purified Saponins}

\subsubsection{Saponin Composition of the Butanol Fractions and Purified Compounds}

The butanol fractions of the three most active sea cucumber extracts in this study consisted mainly of saponin compounds. Compound diversity and relative intensity of saponin compounds detected in the butanol fractions was highest in B. argus (Figure 8). Further analyses of the saponin composition revealed that the butanol fraction of $S$. chloronotus contained merely saponin molecules with higher molecular masses compared to H. fuscopunctata and B. argus.

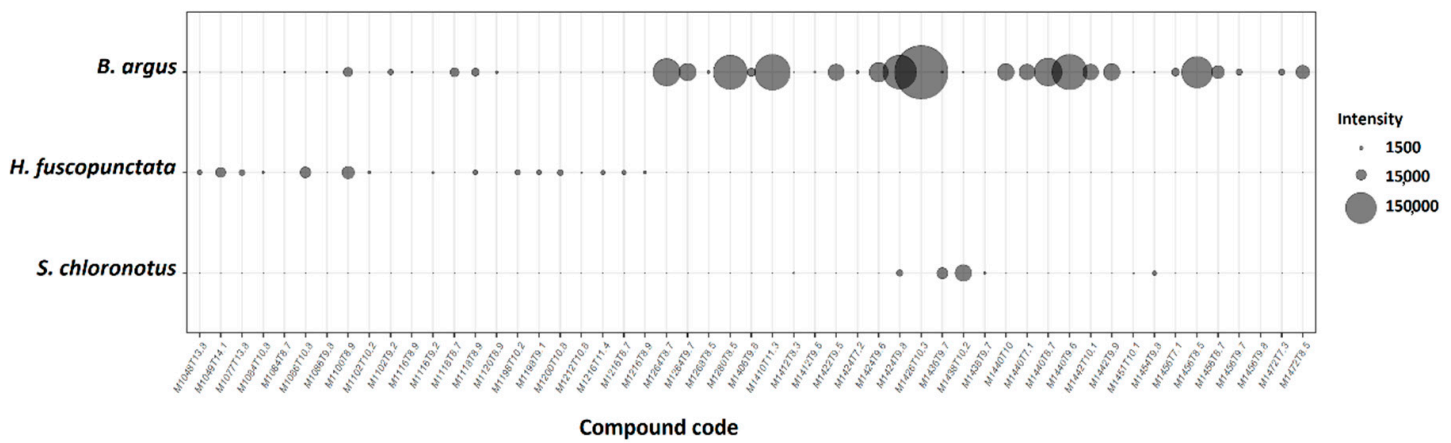

Figure 8. Major saponin compounds detected in the butanol fractions from the crude extracts of the three most active sea cucumber species (peak area $\geq 10^{3}$ ). Compound code represent the exact mass ( $\mathrm{M}$ in Da), and retention time ( $\mathrm{T}$ in $\mathrm{min}$ ). The compounds code of M1426T10.3 related to bivittoside D, and M1410T11.3 related to bivittoside $C$.

Among the detected saponin compounds in B. argus, two of the most dominant compounds were isolated. According to the MarinLit database, both compounds had previously been isolated and structurally characterized as bivittoside $D(\mathrm{~m} / \mathrm{z} 1426.698)$ and $\mathrm{C}(\mathrm{m} / \mathrm{z} 1410.703$; cf. Figure 9$)$ in different species of genus Bohadschia $[50,51]$. Thus, an ongoing study has elucidated in detail the structure of several isolated saponin molecules (including bivittoside $D$ and bivittoside $C$ ) by using a combination of mass spectrometry (MS) and nuclear magnetic resonance (NMR) spectroscopy, thereby confirming their structures (Kamyab et al., in preparation). 


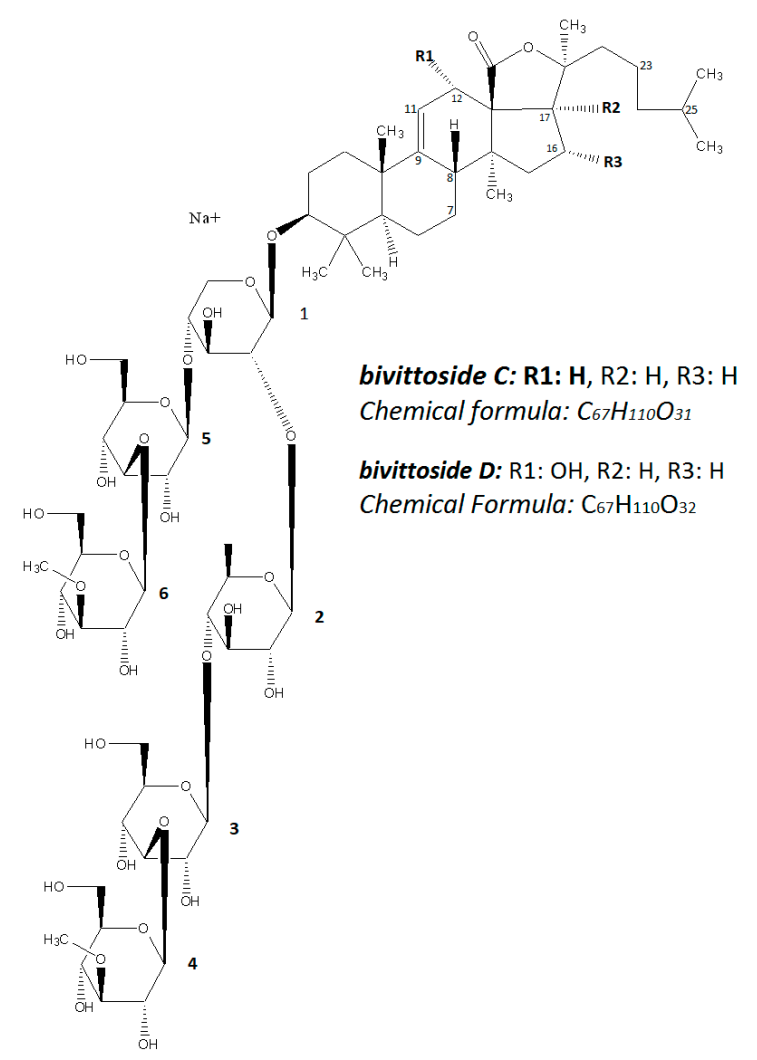

Figure 9. Structure of the two saponin molecules isolated from B. argus (Produced with ChemDraw, version 16.0.1.1(77)).

2.2.2. Fish Feeding Assays with Saponin Purified Fractions of the Three Most Active Sea Cucumbers as well as Two Selected Saponin Compounds Isolated from B. argus

The assays with the butanol fractions and the purified compounds showed varying results in feeding deterrence of the puffer fish C. solandri. That is, the butanol fraction of B. argus and S. chloronotus as well as bivittoside $D$ deterred significantly puffer fish feeding. On the other hand, bivittoside $C$ had no deterrent effect on feeding by C. solandri (Figure 10).

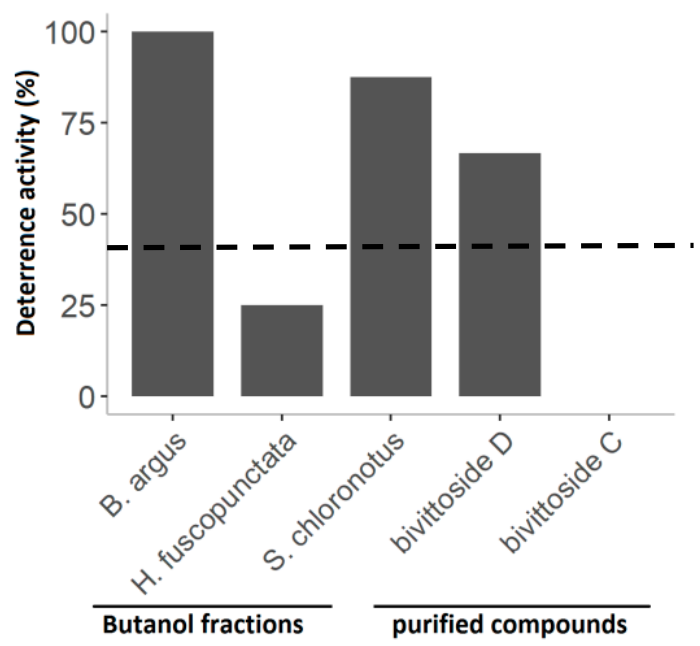

Figure 10. Percent deterrent activity of the butanol fractions from the three most active sea cucumber extracts, as well as two purified compounds (i.e., bivittoside $D$ and bivittoside $C$ ) from B. argus. The line at $40 \%$ indicates significant deterrence ( $p<0.05$, Fisher's exact test, 1-tailed). 


\subsubsection{Cytotoxicity Test: Brine Shrimp Assay}

Similar to the crude extracts, the cytotoxicity of the butanol fractions, as well as the purified compounds, was concentration-dependent. While all tested butanol fractions showed pronounced cytotoxic activity against brine shrimp nauplii larvae (B. argus $\mathrm{LC}_{50}=0.018 \mu \mathrm{g} \mathrm{mL} \mathrm{m}^{-1} \pm \mathrm{SE}=0.008$ and S. chloronotus $0.017 \mu \mathrm{g} \mathrm{mL} \mathrm{L}^{-1} \pm 0.006$ ), the H. fuscopunctata fraction revealed an approximately 10-fold lower cytotoxicity with a $\mathrm{LC}_{50}$ of $0.117 \mu \mathrm{g} \mathrm{mL} \mathrm{m}^{-1} \pm 0.007$ (Figure 11). Bivittoside $D$ (M1426T10.3) and bivittoisde C (M1410T11.3) showed also differences in their bioactivities. That is, bivittoside $D$ displayed 10 -fold stronger cytotoxicity $\left(0.013 \mu \mathrm{g} \mathrm{mL} \mathrm{m}^{-1} \pm 0.006\right)$ compared to bivittoside $C$ $\left(0.164 \mu \mathrm{g} \mathrm{mL} \mathrm{m}^{-1} \pm 0.003\right)$.

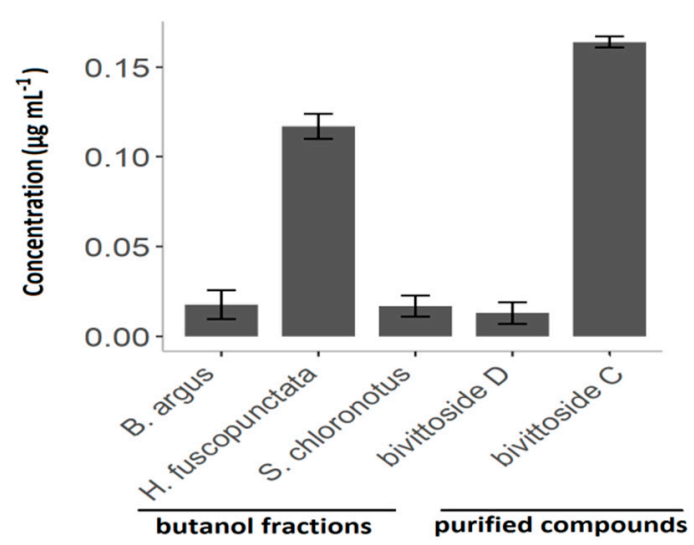

Figure 11. $\mathrm{LC}_{50}$ concentration of the sea cucumber crude extracts against brine shrimp larvae after $48 \mathrm{~h}$. Results express mean values \pm standard error.

\section{Discussion}

Sea cucumbers are mostly deposit-feeding, slow-moving and exposed invertebrates. Although some physical defenses such as spikes (i.e., in genus Bohadschia, H. atra, H. leucospilota [25]), secretion of red fluid (i.e., in H. atra) and thickening or swelling of integuments (i.e., in Holothuria fuscogilva [25] and Holothuria cinerascens [52]) are reported in some species, this group of organisms often relies strongly on chemical defenses to deter predators, compete with other species or fight off pathogenic microorganisms. Studies on the defense mechanisms of different species of sea cucumber revealed that chemical compounds, particularly saponin molecules, protect these organisms against predators and pathogenic microorganisms $[25,37,53,54]$.

The results of this study clearly demonstrate that most of the tested sea cucumber species were chemically well defended against feeding by fishes (11 of 14 tested extracts were deterrent, cf. Figure 2). Antimicrobial activity was even more pronounced, with all extracts displaying greater activity against environmental pathogenic bacteria compared to non-pathogenic bacteria (Figure 5). In addition, most of the extracts with antimicrobial activities revealed also medium cytotoxic effects to brine shrimp larvae (Figure 4, Table 1). Saponins are known bioactive compounds found in Holothurians; however, quantification of the total saponin concentration as well as the composition of saponin species demonstrated that not just the amount of saponins but also the chemical structure/type of saponins were important for the observed chemical defenses (Figures 7, 10 and 11, Figures S1 and S2). Extracts of $H$. atra and $H$. whitmaei had the lowest saponin concentrations but still deterred feeding by C. solandri, and likewise they still displayed weak antimicrobial activity at least against pathogenic bacteria (cf. Figure 5), indicating that not only the overall concentration of saponins but also their chemical structure is important for their defensive function. This is corroborated by the extract of S. maculata, which had higher saponin concentrations than H. atra and H. whitmaei but did not display any fish deterrent activity and only moderate and no activity against pathogenic and non-pathogenic bacteria, respectively. 
By studying the butanol fractions that consisted mostly of saponin molecules, as well as by testing the purified saponin compounds (bivittoside $D$ and $C$ ), we could demonstrate that both the chemical structure and diversity of saponin molecules play a crucial role in their overall bioactivities. We observed that although the butanol fraction of $S$. chloronotus had the lowest diversity of saponins (Figure 8, Figure S1), this fraction showed strong cytotoxicity and deterred feeding by the puffer fish significantly compared to $H$. fuscopunctata. The saponin composition of $S$. chloronotus contained mainly higher molecular weight saponin molecules, whereas $H$. fuscopunctata had lower molecular weight saponin molecules. Furthermore, we observed that among the two relatively heavy saponin molecules isolated from B. argus, bivittoside $D(m / z$ 1426.698) showed stronger cytotoxic effects and deterred fish feeding significantly, whereas bivittoside $C(\mathrm{~m} / \mathrm{z}$ 1410.703) did not reveal antifeeding activities (Figure 10). Similarly, in a previous study, we observed that the same saponin molecule (i.e., bivittoside $D$ ) showed a strong antifouling activity [40], indicating that the presence/absence of a particular functional group within the saponin molecule considerably affects its bioactivity. To assess the differences in chemical defenses between the different sea cucumber families in more detail, we looked at the bioactivities of each family separately.

\subsection{Family Holothuriidae}

For the family Holothuriidae, the three genera Holothuria, Bohadschia and Actinopyga were investigated. Species of the genus Holothuria have different defensive strategies based on their habitats and present predation pressure. Some species hide under rocks, in reef crevices or cover themselves with sand during the day and usually display nocturnal behavior when they leave the hiding places to forage. Other species in this family, however, live exposed. For example, $H$. hilla is usually concealed under coral slabs, within sea grass beds or sandy reef flats [55]. It has been shown that the toxicity (i.e., chemical defense) of $H$. hilla was not effective enough against predation by the snail Tonna perdix, and thus the cryptic behavior is the most effective way to reduce the risks of being attacked by predators (i.e., T. perdix; $[9,30,31,52])$. Correspondingly, we observed that crude extract of $H$. hilla had low cytotoxicity and was palatable for the puffer fish (C. solandri), despite containing the highest total saponin concentration (along with H. edulis). The latter two species, along with $H$. atra and H. whitmaei, contain more sulfated saponin compounds, which enables sea cucumbers to defend quickly against predators in the time they need [31]. Furthermore, although $H$. hilla and $H$. whitmaei are the only two species of genus Holothuria with lobulated CTs ([55]; Figure 1), they use another defensive mechanism called evisceration to defend themselves (Table 1). After attack, the sea cucumbers start with primary contractions of the body, thereby expelling the entire digestive system, gonads and respiratory trees through the cloacae [52]. It has been proposed that most of the chemical compounds will be found in higher concentrations in the viscera than in the outer part of their body [56], thereby protecting the animal when evisceration happens. However, we only analyzed the biological activities of the whole organisms.

H. whitmaei, H. edulis and H. fuscopunctata (or H. axiloga; [57]) have been observed semi-sheltered on coral reefs, lagoons and sea grass beds [55]. However, in some references, H. whitmaei has been misidentified as $H$. nobilis [55], limiting reliable reports about bioactive compounds. H. edulis is mainly nocturnal and has a cryptic behavior [29]. While H. fuscopunctata and H. edulis do not have morphological defense mechanisms, they seem to rely on chemical defenses, displaying high deterrent activities (Figure 2) and medium cytotoxicity $\left(\mathrm{LC}_{50}=337.7 \mathrm{ppm} \pm 0.5 ; \mathrm{LC}_{50}=356.2 \pm 0.1 \mathrm{ppm}\right.$, respectively; Figure 4), which may correlate with the nature of their saponin compositions as well as their total saponin concentrations (Figure 6, Table 1). Similarly, Althunibat et al. (2013) reported the cytotoxicity of organic extracts of H. edulis against cancer cells (TE1 cells (i.e., human esophageal carcinoma), due to the presence of hydrophilic and hydrophobic active compounds (i.e., most probably saponins and sphingoid-based compounds and fatty acids; [58]). The other species of the genus Holothuria which does not have CTs is H. atra. Under stress conditions, H. atra secretes either some red fluid, which contains only sulfated compounds, or eviscerates the gut system and its left respiratory 
tree [25,31]. Kropp (1982) showed that the released fluid from $H$. atra had a repellant effect on the predatory snail T. perdix [52]. Apparently, this species can live relatively exposed [59], by utilizing the hydrophilic fluid in defense, which could explain partially the deterrent activities (Figure 2) and cytotoxicity (Figures 3 and 4 ) of $H$. atra crude extracts. Furthermore, in our study the antibacterial activities of $H$. atra were limited to only two pathogenic strains. This coincides with the findings of Farouk and his colleagues (2007), which showed that the antibacterial activities of $H$. atra extracts are due to the presence of distinct bacterial communities in the coelomic fluid and not the coelomic fluid itself [60]. However, Jawahar Abraham et al. (2002) mentioned that this species along with A. echinites and two other species of sea cucumber had antibacterial activities against clinically relevant strains such as E. coli, Aeromonas hydrophila, Enterococcus sp., Pseudomonas aeroginosa, Klebsiella pneumonia, Staphylococcus aureus, Salmonella typhi and Vibrio harveyi [17].

The other commonly observed members of the family Holothuriidae on coral reefs are Bohadschia and Actinopyga, which are deeply diverged from the other species (Figure 1; [61]). The genus Bohadschia is found in lagoon-type and sandy reef slope habitats, where they either occur exposed or slightly covered in sediments [62]. It contains smooth CTs as possible defense [62]. Our study showed that all species of genus Bohadschia had the strongest deterrent effect on the puffer fish (Figure 2) and the highest toxicity to brine shrimp nauplii larvae (Figure 4), whereas extracts revealed medium activities against a few environmental tested bacteria (Figures 5, 6 and 8, Table 1). Among this family, B. argus had the highest saponin concentration after Actinopyga $\left(1.13 \mathrm{mg} \mathrm{mL}^{-1} \pm 0.02\right.$; Figures 6 and 7). High biological activities in Bohadschia were also demonstrated by Kuznetsova et al. (1982) and Lakshmi et al. (2012), who further found that glycosides (i.e., bivittoside $D$ ) in B. vitiensis are responsible for antifungal activity against C. albicans [63,64]. In parallel, the studies of Kitagawa et al. (1989) and Lakshmi et al. (2014) on B. argus, Bohadschia sp. and S. chloronotus confirmed the antifungal activities of their saponins against $C$. albicans, Candida tropicalis, Candida utilis and Candida krusei $[50,65]$. The above observations can be related to the presence of chemical and physical defense mechanisms in Bohadschia, since the members of this genus have well-developed, expellable and extremely sticky CTs that contain chemical deterrents, particularly non-sulfated and non-oxidized saponin compounds that can be retained for longer in the tubules and body cavity, resulting in higher unpalatability of their producers $[31,66]$. Evisceration of CTs could act as a physical defense, as the glue-like CTs possibly get stuck on the skin of attacking fish predators [66].

Actinopyga, being taxonomically most similar to Bohadschia, can be found in similar habitats such as shallow waters, outer reef flats and seagrass beds, in tropical and temperate regions [55]. These species prefer exposed areas, and they are active during day and night [55]. Unlike Bohadschia, they have lobulated CTs like H. hilla and H. whitmaei $[22,23,67]$. Results of the current study showed that Actinopyga extracts deter feeding by the puffer fish. Furthermore, the average toxicity, as well as total saponin concentration, of genus Actinopyga was higher than in the genus Bohadschia. The results are in agreement with quantitative and qualitative studies of saponin molecules of Bohadschia subrubra and A. echinites by Van Dyck et al. (2010; [42]). The author described a possible evolutionary shift of CTs from "adhesive-based" to "toxic-based" defensive mechanism and declared that lobulated CTs in members of genus Actinopyga contain more sulfated and oxidized saponins that can be used under strong predation pressure by partially exposing, but not completely ejecting, the tubules to predators [31,42]. Thus, it seems that this species uses both chemical (i.e., saponins) and physical (i.e., CTs) defense mechanisms to protect itself against predators. Our studies on the antibacterial activities of Actnipyga revealed that $A$. echinites had strong antibacterial activities against two environmental pathogenic bacteria (i.e., Rhodococcus corynebacterioides. and Aurantimonas coralicida), while A. mauritiana inhibited the growth of five strains (Figure 5, Table 1, Table S2). Likewise, Jawahar and his colleagues (2002) reported antibacterial activities of the ethanolic extract of A. echinites against the human pathogen Staphylococcus aureus [17], while Kuznetsova et al. (1982) mentioned the inhibition of the fungus $C$. albicans by $A$. mauritiana extract, most likely due to the presence of saponin molecules (i.e., Holothurin A; [63]). 


\subsection{Family Stichopodiidae}

From this family, the biological activities of $S$. chloronotus and T. ananas were analyzed. Shedding of body wall is the only defense behavior reported from the Synallactida clade [46,52]. Like H. hilla and H. atra, a potential predator of S. chloronotus is T. perdix, which is less susceptible to toxic compounds produced/secreted by sea cucumbers [52]. Yamanouchi (1955) and Bakus (1981) determined in fish feeding experiments using different marine fishes (i.e., Enedrias nebulosus, Girella punctata, Pomacentrus coelestis, Plotosus anguillaris and Thallosoma cupido) as well as fresh water fishes (i.e., Carasius auratus, gold fish and different varieties of Oryzias latipes) that extracts of B. argus, S. chloronotus and T. ananas deterred feeding [30,68]. Similarly, our feeding assays showed that $S$. chloronotus and $T$. ananas extracts deterred feeding by the puffer fish; however, the effect was not as strong as extracts of the different Bohadschia species (Holothuriidae; Figure 2), and they had medium brine shrimp toxicity $\left(\mathrm{LC}_{50}=234.70 \mathrm{ppm} \pm 0.9 ; \mathrm{LC} 50=441.62 \mathrm{ppm} \pm 0.8\right.$, respectively; Figures 3 and 4). Both S. chloronotus and T. ananas contained saponin concentrations as high as in Bohadschia (Figures 6 and 7), although they lacked CTs. It had been reported that, similar to most Holothuriidae members and T. anana, not only S. chloronotus contains sulfated triglycosides and fucosylated chondroitin sulfate [69-71]. Extracts of this species contain non-sulfated saponins, and similar to Bohadschia bivitatta, their chemical compounds are less soluble in water and contain hexosides as the main component of its glycosidic fraction that allows the saponins to be retained for longer in the source tissue/organ (i.e., body wall), and this provides a conditioned response in the predator $[70,72-74]$.

\subsection{Family Synaptidae}

Among inhabitants of coral reefs, S. maculata is the most divergent member of Holothuroidea (Figure 1; [8]), with different defensive mechanisms (i.e., autotomy) than the other studied species [75,76]. Moreover, this species is active during the night and possesses very thin and transparent connective tissues $[32,77]$ that may affect their visibility. These potential camouflage properties might explain the lack of chemical feeding deterrence that was observed during the feeding experiments with C. solandri. The extract was also not toxic for brine shrimp larvae, which correlated with its relatively low saponin concentration (Figure 7). Similarly, Ponnomarenko and his colleagues (2001) reported that $S$. maculata was much less toxic compared to the studied dendrochirotids (i.e., Cucumaria sp. and Cucumaria bifurcates; [78]). The author mentioned that the low toxicity of $S$. maculata is probably due to the presence of high concentrations of $\Delta^{5}$ sterols as well as reported non-toxic glycosides. Moreover, Flammang and Conand (2004) mentioned that instead of triterpene glycosides, the presence of vesicular cells in the tentacles of $S$. maculata gave protective functionality to this organ [79].

\section{Materials and Methods}

\subsection{Sea Cucumber Collection and Identification}

Sea cucumbers were collected in July 2016, at Family Beach, Apra Harbor $\left(13^{\circ} 27^{\prime}\right.$ N, $144^{\circ} 38^{\prime}$ E) and Luminao Reef in Guam (13 $27^{\prime} 054^{\prime \prime}$ N, $144^{\circ} 38^{\prime} 053^{\prime \prime}$ E). Sea cucumbers were identified together with the known sea cucumber specialist Prof. Alexander Kerr (University of Guam Marine Laboratory, University of Guam, Mangilao, Guam) based on coloration and morphology. The tested sea cucumbers included fourteen species from three orders (Holothuriida, Synallactida [46] and Apodida [80]; Figure 1). From the family Holothuriidae, we studied three species of genus Bohadschia [81], two species of Actinopyga [82] and 6 species of Holothuria ([83]. From the family of Stichopodidae, species of Stichopus chloronotus [80] and Thelenota ananas [81] were investigated. We also analyzed a species from the order of Apodida (i.e., Synapta maculata; [84]. All collected specimens were weighted before freezing to establish their wet weights. For a subset of species, 2-3 individuals were collected, extracted and screened separately in the various bioassays (H. atra, A. echinites, S. chloronotus and B. argus). This was done to assess the intraspecific variability. 


\subsection{Extraction}

Frozen specimens were freeze-dried and ground to a fine powder using a blender. Macro extractions were performed for $15 \mathrm{~g}$ of whole organisms three consecutive times using a 1:1 ratio $(v / v)$ of methanol $(\mathrm{MeOH})$ and ethyl acetate (EtOAc) and finally with $100 \% \mathrm{MeOH}$ overnight. For each gram of freeze-dried sea cucumber, we used $10 \mathrm{~mL}$ of solvent (AppliChem GmbH, Darmstadt, Germany). Each extract was filtered through Whatman No 1 filter (Diameter: $150 \mathrm{~mm}$, Grade: 3 hw, Sartorius GmbH, 37979, Göttingen, Germany), and the remaining extract was dried using rotary evaporation (Rotavapor RII, BUCHI, Switzerland) and a centrifugal vacuum concentrator (Speedvac: Christ RVC 2-25 Co plus; Freeze dryer: Christ Alpha 2-4 LD plus). The obtained extracts were weighed and kept frozen at $-20^{\circ} \mathrm{C}$ until used for the different biological assays (see Table S1).

Sample fractionation and purification. Three of the most active crude extracts of sea cucumbers from three genera of Bohadschia, Holothuria and Stichopus (i.e., B. argus, H. fuscopunctata and S. chloronotus) were partitioned using EtOAc: $\mathrm{H}_{2} \mathrm{O}: \mathrm{BuOH}$ (1:1:1). The obtained butanol fractions that showed a higher diversity of saponin molecules (Figure S1), as well as stronger antibacterial and antiviral activities (unpublished data), were selected for further ecological assays. Additionally, the three most active butanol fractions were further fractionated by solid phase extraction (SPE) chromatography using a SPE column (SUPELCLEAN LC $18,60 \mathrm{~mL} / 10 \mathrm{~g}$; Supleco Park, Bellefonte, PA, USA) [85], following the method that was previously described by Kamyab and colleagues (2020; [41]). In brief, after desalting the fractions with $60 \mathrm{~mL} \mathrm{MeOH}$ and preconditioning the columns with $120 \mathrm{~mL}$ distilled water, the concentrated $\mathrm{BuOH}$ fraction was added to the column and washed with the following five elution gradients, using each time a volume of $60 \mathrm{~mL}$ : Fraction A, 100\% $\mathrm{H}_{2} \mathrm{O}$; Fraction $\mathrm{B}, \mathrm{MeOH}: \mathrm{H}_{2} \mathrm{O}$ (50:50); Fraction C, ACN: $\mathrm{H}_{2} \mathrm{O}$ (70:30); Fraction D, 100\% ACN and Fraction E, $\mathrm{CH}_{2} \mathrm{Cl}_{2}: \mathrm{MeOH}(90: 10)$.

Preliminary antimicrobial screening of each SPE fraction from the three most active sea cucumbers showed that the SPE Fraction B and Fraction C (see above) of B. argus had pronounced activities and were further purified using semi-preparative HPLC (Agilent Technologies, 1260 Infinity, Santa Clara, CA, USA) equipped with a PDA detector (Agilent, G4212-60008, Santa Clara, CA, USA). Thus, as described in Kamyab et al., 2020 [40], we used a $C_{18}$ column (Pursuit XRs $5 \mu \mathrm{m}$, $250 \mathrm{~mm} \times 10 \mathrm{~mm}$, Agilent, Santa Clara, CA, USA) with a pre-column $(2.7 \mu \mathrm{m}, 2.1 \mathrm{~mm} \times 5 \mathrm{~mm}$, Agilent, Santa Clara, CA, USA). The two eluents of " $\mathrm{A}$ ", consisting of $95 \% \mathrm{H}_{2} \mathrm{O}$ and $0.1 \%$ of formic acid $98 \%$ (Carl Roth $\mathrm{GmbH}$ ), and "B" consisting of $\mathrm{ACN}$ and $0.1 \%$ formic acid, were used to provide a linear gradient of initial A:B (50\%:50\%). After 4 min with the same gradient, for $32 \mathrm{~min}$, we applied $38 \% \mathrm{~A}: 62 \% \mathrm{~B}$, followed by $4 \mathrm{~min} 100 \% \mathrm{~B}$. A column reconditioning phase was applied for 39-59 min $100 \% \mathrm{~B}$ and $8 \mathrm{~min}$ to $50 \% \mathrm{~A}: 50 \% \mathrm{~B}$ (flow rate $1.5 \mathrm{~mL} \mathrm{~min}^{-1}$ ). Finally, the peak integration of all detected saponins within the tested butanol fraction as well as the two pure compounds were assessed semi-quantitatively (cf. Figures 8 and 12), and these purified fractions/pure compounds were used for the feeding assay and cytotoxicity test.

\subsection{Feeding Deterrent Assay (FA)}

To investigate if the collected sea cucumbers were chemically defended against a potential fish predator, we conducted laboratory feeding assays (FA) using the puffer fish Canthigaster solandri. C. solandri, which is a well-established assay organism to test for feeding deterrent properties against feeding by fishes (see [86]). C. solandri is an abundant benthic fish species in the Indo-Pacific region and known to feed on a variety of marine invertebrates such as poriferans, ascidians, small shrimps, polychaetes and benthic algae [86,87]. Thus, C. solandri has been considered as a model fish predator for testing the feeding deterrence of benthic organisms [86,88-91]. For the FA, 17 individuals were kept separately in $100 \mathrm{~L}$ tanks and fed routinely to avoid any preference patterns [92]. The feeding assays were conducted as described in Rohde et al. 2012 [91] and Helber et al., 2017 [93] (adapted from Pawlik 1995). In short, the artificial diet consisted of the natural volumetric concentration of dried crude extract of $1.5 \mathrm{~mL}$ sea cucumber tissue, $50 \mathrm{mg}$ alginic acid and $75 \mathrm{mg}$ freeze-dried squid mantel topped with distilled water to reach a final volume of $1.5 \mathrm{~mL}$ [94]. Before homogenizing the food 
mixture, one drop of food color was added and finally loaded into a $2 \mathrm{~mL}$ syringe. The syringe tip was submerged in $0.25 \mathrm{M}$ calcium chloride solution $\left(\mathrm{CaCl}_{2}\right)$ and the syringe content slowly emptied. The spaghetti-shaped pellets were carefully rinsed with sea water and then chopped into small pieces $(1 \times 2 \mathrm{~mm})$ suitable for the fish. Control pellets were prepared in the same way without the addition of extracts.

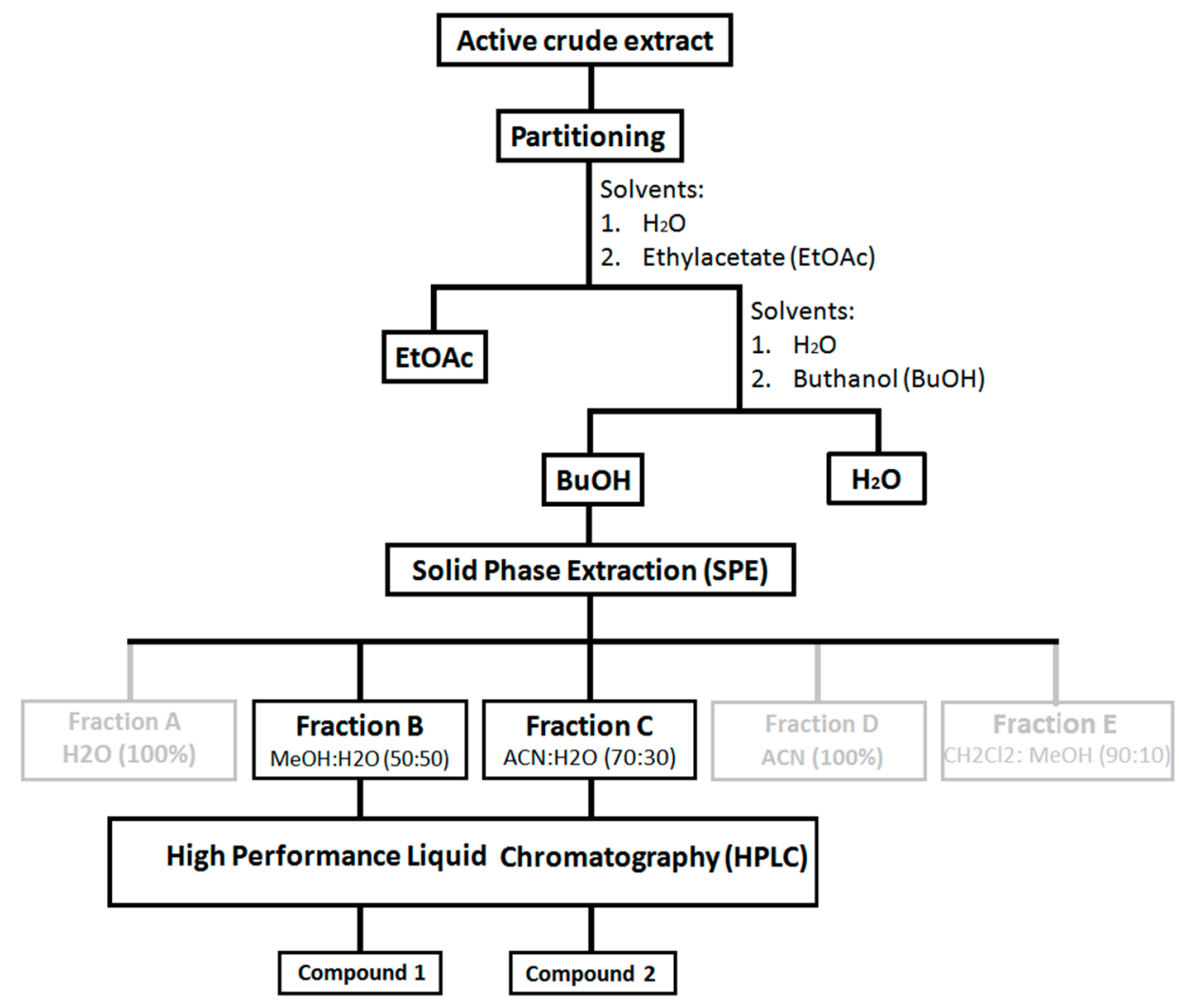

Figure 12. Workflow applied for isolating the bioactive saponin compounds from three most active sea cucumbers, B. argus, H. fuscopunctata and S. chloronotus. Compounds 1 (i.e., bivittoside D) and 2 (i.e., bivittoside C) were both isolated from "Fraction B" and "Fraction C" of B. argus.

To test the degree of feeding deterrence of each crude extract, a control pellet was first fed to each of the puffer fish specimens. If the control pellet was eaten, a pellet containing extract was offered to the fish. In the event that the fish rejected the crude extract pellet, a control pellet was offered to the fish to confirm that it had not ceased feeding. Only if the fish rejected the crude extract pellet and ate the second control pellet was a rejection scored. The feeding deterrence of crude extracts, and replicates of $H$. atra, B. argus, S. chloronotus and A. echinites, were repeated three times per crude extract of each specimen and expressed as deterrence percentage and analyzed using Fisher's exact test [94].

\subsection{Cytotoxicity Test: Brine Shrimp Assay}

To test the cytotoxicity of the crude extracts, we conducted a brine shrimp assay (BSA; [95]). This assay is based on the lethality of nauplii larvae of the laboratory-cultured brine shrimp Artemia salina [96]. For this assay, each crude extract, and replicates of some species (see Figure 1), was dissolved in $\mathrm{MeOH}$ and tested in triplicates in three concentrations $\left(1000 \mu \mathrm{g} \mathrm{mL}{ }^{-1}, 100 \mu \mathrm{g} \mathrm{mL}\right.$ and $10 \mu \mathrm{g} \mathrm{mL}^{-1}$ ) in 6-well plates for calculating $\mathrm{LC}_{50}$. $\mathrm{MeOH}$ was used as a negative control. After the organic solvent evaporated, $5.0 \mathrm{~mL}$ of the sterilized and filtered $(0.45 \mu \mathrm{m}$ pore size $)$ seawater was added. In each multi-well plate, we added 10 newly hatched nauplii brine shrimp larvae. After $12 \mathrm{~h}$ and $24 \mathrm{~h}$ of exposure, surviving larvae were counted and results scored as \% mortality. We finally 
converted the dilutions to their natural logarithm of concentration and calculated the $\mathrm{LC}_{50}$ following regression analysis [49,97].

\subsection{Antimicrobial Test: Agar Diffusion Assay (ADA)}

The antibacterial activity screening of the sea cucumber crude extracts was carried out using the agar disk diffusion assay $[98,99]$. For this test, pathogenic and non-pathogenic environmental bacteria were used in the ADA (Table 2). The bacteria had either been previously isolated from coral reef sites where the sea cucumber had been collected or obtained from the DSMZ-German Collection of Microorganisms and Cell Cultures (strains DSM 14790 and DSM 19607, Braunschweig, Germany). Test strains were inoculated and spread on Marine Broth (Carl Roth $\mathrm{GmbH}$ ) in petri dishes. Crude extract of each species ( $0.5 \mathrm{mg}$ per cellulose disk) was loaded onto the sterilized cellulose filter disc (Ø $6 \mathrm{~mm}$, Rotilabo NO KA07.1, ROTH, Karlsruhe, Germany), dried and finally placed onto the inoculated agar plates. As a negative control, $\mathrm{MeOH}$ instead of crude extract was coated onto the cellulose filter disc. The plates were incubated at $28{ }^{\circ} \mathrm{C}$ for $24 \mathrm{~h}$. The assay was performed in triplicate for each extract. The antibacterial activity was evaluated by measuring the diameter of the growth inhibition zones around each disc (in $\mathrm{mm}$ ) and was scored as weak ( $<10 \mathrm{~mm})$, medium $(10-20 \mathrm{~mm})$ and strong (>20 mm) inhibition (Figure 5). 
Table 2. List of pathogenic and non-pathogenic test panel of bacteria used for Agar diffusion assay (ADA).

\begin{tabular}{|c|c|c|c|c|c|c|c|c|c|}
\hline No. & Gram Test & Phylum & Class & Family & $\begin{array}{l}\text { Accession No. of } \\
\text { Bacterial Isolate }\end{array}$ & $\begin{array}{l}\text { Species (Closest } \\
\text { NCBI Hit) }\end{array}$ & $\begin{array}{l}\text { Accession No. of the } \\
\text { Closest NCBI Hit }\end{array}$ & $\begin{array}{l}\text { Similarity of the } \\
\text { Closest NCBI Hit }\end{array}$ & Pathogen \\
\hline 1656 & positive & Actinobacteria & Actinobacteria & Streptomycetaceae & MG551768 & $\begin{array}{l}\text { Streptomyces } \\
\text { flavoviridis }\end{array}$ & NR_041218 & 100 & non-pathogenic \\
\hline 1668 & negative & Proteobacteria & Alphaproteobacteria & Rhodobacteraceae & MG551772 & Ruegeria areniliticus & NR_109635 & 97.439 & non-pathogenic \\
\hline 1721 & negative & Proteobacteria & Gammaproteobacteria & Alteromonadaceae & MG551801 & $\begin{array}{c}\text { Microbulbifer } \\
\text { variabilis }\end{array}$ & NR_041021 & 99.78 & non-pathogenic \\
\hline 1792 & negative & Proteobacteria & Alphaproteobacteria & Rhodobacteraceae & MG551832 & $\begin{array}{l}\text { Pseudovibrio } \\
\text { denitrificans }\end{array}$ & NR_113946 & 99.784 & non-pathogenic \\
\hline 1348 & negative & Proteobacteria & Gammaproteobacteria & Vibrionaceae & MG711594 & Vibrio maritimus & NR_117551 & 98 & non-pathogenic \\
\hline 1809 & negative & Proteobacteria & Alphaproteobacteria & Rhodobacteraceae & MG551841 & Ruegeria areniliticus & NR_109635 & 98.072 & non-pathogenic \\
\hline 1678 & negative & Proteobacteria & Gammaproteobacteria & Moraxellaceae & MG551777 & Acinetobacter pitii & NR_117930 & 99.663 & $\begin{array}{l}\text { Fish pathogen [100] } \\
\text { and human pathogen } \\
\text { (Pneumonia; [101]) }\end{array}$ \\
\hline WHV 0001 & negative & Proteobacteria & Alphaproteobacteria & Aurantimonadaceae & - & $\begin{array}{l}\text { Aurantimonas } \\
\text { coralicida }\end{array}$ & AY065627 & $\begin{array}{l}\text { Obtained from } \\
\text { DSMZ, Germany }\end{array}$ & $\begin{array}{l}\text { White plague type II } \\
\text { disease [102] }\end{array}$ \\
\hline WHV 0002 & negative & Proteobacteria & Gammaproteobacteria & Vibrionaceae & - & Vibrio shilonii & ATCC BAA-91 & $\begin{array}{l}\text { Obtained from } \\
\text { DSMZ, Germany }\end{array}$ & $\begin{array}{c}\text { Bacterial } \\
\text { bleaching }[103,104]\end{array}$ \\
\hline WHV 0003 & negative & Proteobacteria & Gammaproteobacteria & Vibrionaceae & - & Vibrio coralliilyticus & AJ440005 & $\begin{array}{l}\text { Obtained from } \\
\text { DSMZ, Germany }\end{array}$ & $\begin{array}{l}\text { Bacterial bleaching and } \\
\text { rapid tissue } \\
\text { destruction [105-107] }\end{array}$ \\
\hline 852 & negative & Proteobacteria & Gammaproteobacteria & Moraxellaceae & MG551849 & Acitenobacter soli & NR_044454 & 99 & human pathogen [108] \\
\hline 1334 & negative & Proteobacteria & Gammaproteobacteria & Alteromonadaceae & MG711595 & $\begin{array}{l}\text { Aliagarivorans } \\
\text { marinus }\end{array}$ & FJ952768.1 & 98 & $\begin{array}{l}\text { Pathogenic (White } \\
\text { Plague type II) }\end{array}$ \\
\hline 1682 & positive & Actinobacteria & Actinobacteria & Nocardiaceae & MG551778 & $\begin{array}{c}\text { Rhodococcus } \\
\text { corynebacterioides }\end{array}$ & NR_119107 & 99.343 & human pathogen [109] \\
\hline 1810 & negative & Proteobacteria & Gammaproteobacteria & Enterobacteriaceae & MG551842 & Pantoea eucrina & NR_116246 & 99.299 & human pathogen [110] \\
\hline 1712 & positive & Actinobacteria & Actinobacteria & Micrococcaceae & - & Kocuria turfanensis & txid388357 & 100 & Biosafty class1 [111] \\
\hline
\end{tabular}




\subsection{Total Saponin Concentration}

To study the relationship between the observed bioactivities of the crude extracts and their overall saponin concentrations, the method of [112] was applied to measure the total saponin concentrations of different sea cucumber species (Figure 6). During this vanillin-sulfuric acid colorimetric test, sulfuric acid oxidizes the saponins, thereby converting the saccharide chains to furfural. The reaction of the resulting free hydroxyl group at $\mathrm{C}(3)$ in the steroidal part with vanillin produces a distinctive yellow-brown color [113]. Accordingly, a vanillin-sulfuric acid solution was prepared. Crude extract or double distilled water (blank), vanillin $(8 \% w / v)$ dissolved in ethanol (analytical grade) and sulfuric acid $(72 \% v / v)$ were mixed in a 1:1:10 $(v / v)$ proportion in an ice bath. The test solutions were incubated at $60{ }^{\circ} \mathrm{C}$ in a water bath for $10 \mathrm{~min}$. To stop the reaction, samples were cooled down on ice for $2 \mathrm{~min}$. A standard curve was made by serial diluting a $5 \mathrm{mg} \mathrm{mL}^{-1}$ Quillaja bark saponin solution in distilled water (AppliChem GmbH, 64291, Darmstadt, Germany). Finally, the absorbance was measured with a 96-well microplate reader at $540 \mathrm{~nm}$.

\subsection{Saponin Composition and Dereplication}

Following methods described in a previous study [40], we analyzed the major saponin compounds in the butanol fractions of the three most active sea cucumber crude extracts, namely B. argus, $H$. fuscopunctata and S. chloronotus. In brief, an aliquot of each butanol fraction and purified compound was analyzed by ultra-performance liquid chromatography-high resolution mass spectrometry (UPLC-HRMS) using a Waters Acquity UPLC BEH C 18 column $(1.7 \mu \mathrm{m}, 2.1 \mathrm{~mm} \times 50 \mathrm{~mm})$ for chromatographic separation. The UPLC system was an ACQUITY H-Class System (Waters Co., Milford, MA, USA) that was coupled to a Synapt G2-Si high-resolution Q-ToF-MS (Waters Co., Manchester, UK) equipped with a LockSpray dual electrospray ion source operated in positive (POS) ionization mode. The calibration of the Q-ToF-MS system was done in resolution mode over a mass-to-charge $(\mathrm{m} / \mathrm{z})$ value ranging from 50 to 2000 Dalton by using a $0.5 \mathrm{mmol} \mathrm{L}-1$ sodium formate solution. We used leucine enkephalin as the lock mass and a reference ion for POS mode $\left([\mathrm{m} / z 556.277 \mathrm{M}+\mathrm{H}]^{+}\right)$to verify a mass tolerance for all LC-MS or LC-MS/MS experiments of less than one ppm. The MS ${ }^{\mathrm{e}}$ data acquisition function was used for collecting mass spectral data (cf. [40]).

Data treatment. The detected mass data $\left(\mathrm{MS}^{1}\right)$ of saponin compounds presented in the fractions were compared with the molecular masses of known saponins identified in the MarinLit database. Finally, we identified saponin molecules as MxTx, where " $\mathrm{M}^{\prime}$ refers to the exact mass $m / z$ [M], and " $\mathrm{T}$ " refers to the retention time (RT). Moreover, the abundance of each saponin molecule was calculated based on the integrated area of the respective peak. LC/MS spectra of analyzed fractions and the two pure compounds are shown in Figures S1 and S2 in the Supplementary Materials.

\subsection{Ecological Assays of Fractions and Purified Compounds}

To confirm whether saponin compounds are responsible molecules to deter puffer fish and also had cytotoxic effects on brine shrimps, we conducted the same experiment (see Sections 4.3 and 4.4) with the butanol fractions of the most active sea cucumber species (i.e., B. argus, H. fuscopunctata and S. chloronotus) and the two purified compounds bivittoside D (M1426T10.3) and bivittoside C (M1410T11.3). For calculating lethal concentrations $\left(\mathrm{LC}_{50}\right)$, binominal regression models using a probit (assumes normal distribution) were chosen as the best link function and were computed [114,115].

\subsection{Statistical Analysis}

Statistical analyses were performed using the statistical software RStudio (Version 1.2.5019, 2009-2019 RStudio, Inc, Boston, MA, website: www.rstudio.com) and Sigmaplot (Version 11.0). The significance levels for all tests were $5 \%(p<0.05)$. Values are reported as mean and standard error $(\mu \pm S E)$, unless otherwise indicated. All graphs were plotted using the R package "ggplot2". 
For calculating $\mathrm{LC}_{50}$, a combination of "lc" function [116] and R packages "ecotoxicology" and "ecotox" were used to first adjust the best link function (probit, logit or cloglog), and calculating the $\mathrm{LC}_{50}$.

\section{Conclusions}

The data provided here suggest that there is indeed a relationship between the chemical and physical defense mechanisms of sea cucumbers and their ecological strategies. All tested sea cucumbers that did not have cryptic behavior chemically deterred feeding by the puffer fish C. solandri. In addition, members of each family displayed peculiar morphological defensive strategies such as smooth CTs (e.g., in Bohadschia), lobulated CTs (e.g., in Actinopyga and two species of Holothuria), shedding (e.g., in S. chloronotus) and autotomy (e.g., in S. maculata). Bioactivity assays of the here tested crude extracts, as well as the saponin enriched fractions and purified saponin molecules, demonstrated that not only quantity but mostly the molecular structure of the defense molecule is responsible for the observed bioactivities. Holothurians can therefore increase their survival and fitness by employing different chemical defense mechanisms or by using a combination of chemical and morphological defenses. Our observations and experiments on the chemical ecology of marine organisms can lead not only to a better understanding of their ecology and environmental roles but can also lead to a better selection of organisms rich in bioactive compounds and thus aid in the discovery of novel pharmacologically active natural products in the near future. Given the pronounced bioactivities in our ecological assays, we suggest that the sea cucumber genus Bohadschia should be investigated in more detail to identify potential pharmacologically active compounds.

Supplementary Materials: The following are available online. Table S1: Sea cucumber displaced volume, dry weight of sea samples (DW) and yield of crude extract, Table S2: Antibacterial activities of organic crude extracts of sea cucumbers based on inhibition zone (weak $<10 \mathrm{~mm}$, medium $(10-20 \mathrm{~mm}$ ), strong $>20 \mathrm{~mm}$ ). "-" means no growth inhibition. Figure S1: LC/MS spectra of the butanol fractions isolated from the three most active crude extracts of $H$. fuscopunctata, B. argus and S. chloronotus. Y-axis shows the relative peak intensity in \%, and on the $x$-axis, the retention time is given in minutes, Figure S2: LC/MS spectra of the purified compounds isolated from $B$. argus (i.e., bivittoside $C$ and $D$ ). $Y$-axis shows the relative peak intensity in $\%$ and, on the $x$-axis, the retention time is given in minutes.

Author Contributions: E.K. and P.J.S. conceived and designed the experiments; P.J.S. collected the specimens. E.K. performed the experiments; E.K., S.R., M.Y.K. and P.J.S. analyzed the data; E.K., S.R., M.Y.K., P.J.S. wrote and edited the paper. All authors have read and agreed to the published version of the manuscript.

Funding: The authors acknowledge funding by the Federal Ministry of Education and Research (BMBF) via the Germany-Indonesia Antiinfective Cooperation (GINAICO), grant number 16GW0106, and Deutsche Forschungsgemeinschaft (DFG) funding INST 1841147.1FUGG for the high-resolution mass spectrometer Waters Synapt G2-Si.

Acknowledgments: The authors thank Alexander Kerr at the University of Guam Marine Laboratory for assistance with the identification of the collected sea cucumbers. All permits for sample collection and export (certificate of origin) were obtained from the Guam Department of Agriculture, Division of Aquatic and Wildlife Resources (DAWR). We thank the aquarium team of the environmental biochemistry group at the University of Oldenburg for their assistance. We also thank anonymous reviewers for valuable comments and their time, which helped to improve the manuscript.

Conflicts of Interest: The authors declare no conflict of interest. The funders had no role in the design of the study; in the collection, analyses, or interpretation of data; in the writing of the manuscript, or in the decision to publish the results.

\section{References}

1. Aneiros, A.; Garateix, A. Bioactive peptides from marine sources: Pharmacological properties and isolation procedures. J. Chromatogr. B 2004, 803, 41-53. [CrossRef] [PubMed]

2. Kim, S.K.; Rajapakse, N.; Shahidi, F. Marine Nutraceuticals and Functional Foods; Barrow, C., Shahidi, F., Eds.; CRC Press: Boca Ratón, CA, USA, 2008.

3. Brusca, R.C.; Brusca, G.J. Invertebrates, 2nd ed.; Sinauer Associates, Inc.: Sunderland, MA, USA, 1990; ISBN 0-87893-097-3. 
4. Turbeville, J.M.; Schulz, J.R.; Raff, R. A Deuterostome phylogeny and the sister group of the chordates: Evidence from molecules and morphology. Mol. Biol. Evol. 1994, 11, 648-655. [CrossRef] [PubMed]

5. Mojica, E.R.E.; Merca, F. Lectin from the body walls of black sea cucumber (Holothuria atra Jäger). Philipp. J. Sci. 2004, 133, 77-85.

6. Wilkie, I.C. Mutable Collagenous Tissue: Overview and Biotechnological Perspective. In Progress in Molecular and Subcellular Biology Subseries Marine Molecular Biotechnology; Matranga, V., Ed.; Springer: Berlin/Heidelberg, Germany, 2005; Volume 39.

7. Schoenmakers, H.J.N.; Voogt, P.A. In Vitro biosynthesis of steroids from progesterone by the ovaries and pyloric ceca of the starfish Asterias rubens. Gen. Comp. Endocrinol. 1980, 41, 408-416. [CrossRef]

8. Kerr, A.M. M. Evolution and Systematics of Holothuroidea (Echinodermata). Ph.D. Dissertation, Yale University, New Haven, CT, USA, 2000.

9. Francour, P. Predation on Holothurians: A literature review. Invertebr. Biol. 1997, 116, 52-60. [CrossRef]

10. Althunibat, O.Y.; Bin Hashim, R.; Taher, M.; Mohd Daud, J.; Ikeda, M.-A.; Zali, B.I. In Vitro Antioxidant and Antiproliferative Activities of Three Malaysian Sea Cucumber Species. Eur. J. Sci. Res. 2009, 37, 376-387.

11. Uthicke, S. Interactions between sediment-feeders and microalgae on coral reefs: Grazing losses versus production enhancement. Mar. Ecol. Prog. Ser. 2001, 210, 125-138. [CrossRef]

12. Uthicke, S. Sediment bioturbation and impact of feeding activity of Holothuria (Halodeima) atra and Stichopus chloronotus, two sediment feeding holothurians, at Lizard Island, great barrier reef. Bull. Mar. Sci. 1999, 64, 129-141.

13. Purcell, S.W.; Conand, C.; Uthicke, S.; Byrne, M. Ecological Roles of Exploited Sea Cucumbers. Oceanogr. Mar. Biol. Annu. Rev. 2016, 54, 367-386. [CrossRef]

14. González-Wangüemert, M.; Aydin, M.; Conand, C. Assessment of sea cucumber populations from the Aegean Sea (Turkey): First insights to sustainable management of new fisheries. Ocean. Coast. Manag. 2014, 92, 87-94. [CrossRef]

15. Kazanidis, G.; Antoniadou, C.; Lolas, A.P.; Neofitou, N.; Vafidis, D.; Chintiroglou, C.; Neofitou, C. Population dynamics and reproduction of Holothuria tubulosa (Holothuroidea: Echinodermata) in the Aegean Sea. J. Mar. Biol. Assoc. UK 2010, 90, 895-901. [CrossRef]

16. Schneider, K.; Silverman, J.; Woolsey, E.; Eriksson, H.; Byrne, M.; Caldeira, K. Potential influence of sea cucumbers on coral reef $\mathrm{CaCO}_{3}$ budget: A case study at One Tree Reef. J. Geophys. Res. Biogeosci. 2011, 116, 1-8. [CrossRef]

17. Abraham, T.J.; Nagarajan, J.; Shanmugam, S.A. Antimicrobial substances of potential biomedical importance from holothurian species. Indian J. Mar. Sci. 2002, 31, 161-164.

18. Williams, D.H.; Stone, M.J.; Hauck, P.R.; Rahman, S.K. Why are secondary metabolites (Natural Products) biosynthesized. J. Nat. Prod. 1989, 52, 1189-1208. [CrossRef]

19. Mckey, D. Adaptive Patterns in Alkaloid Physiology. Am. Nat. 1974, 108, 305-320. [CrossRef]

20. Schupp, P.; Eder, C.; Paul, V.; Proksch, P. Distribution of secondary metabolites in the sponge Oceanapia sp. and its ecological implications. Mar. Biol. 1999, 135, 573-580. [CrossRef]

21. Zangerl, A.R.; Rutledge, C.E. The Probability of Attack and Patterns of Constitutive and Induced Defense: A Test of Optimal Defense Theory. Am. Nat. 1996, 147, 599-608. [CrossRef]

22. Kerr, A.M.; Janies, D.A.; Clouse, R.M.; Samyn, Y.; Kuszak, J.; Kim, J. Molecular phylogeny of coral-reef sea cucumbers (Holothuriidae: Aspidochirotida) based on 16S mitochondrial ribosomal DNA sequence. Mar. Biotechnol. 2004, 7, 53-60. [CrossRef]

23. VandenSpiegel, D.; Jangoux, M. Fine Structure and Behaviour of the So-called Cuvierian Organs in the Holothuroid Genus Actinopyga (Echinodermata). Acta Zool. 1993, 74, 43-50. [CrossRef]

24. Samyn, Y.; Appeltans, W.; Kerr, A.M. Phylogeny of Labidodemas and the Holothuriidae (Holothuroidea: Aspidochirotida) as inferred from morphology. Zool. J. Linn. Soc. 2005, 144, 103-120. [CrossRef]

25. Castillo, J.A. Predator Defense Mechanisms in Shallow Water Sea Cucumbers (Holothuroidea). Stud. Res. Pap. 2006, 12, 14. [CrossRef]

26. Delia, T.J.; Hertel, L.W. Characterization of the aglycones of the toxic principle of the sea cucumber Holothuria atra. Toxicon 1977, 15, 461-462. [CrossRef]

27. Domantay, J.S. Autotomy in holothurians. Nat. Appl. Sci. Bull. Univ. Philipp. 1931, 1, 389-404.

28. Miller, J.E.; Pawson, D.L. Swimming sea cucumbers (Echinodermata: Holothuroidea): A survey, with analysis of swimming behavior in four bathyal species. Smithson. Contrib. Mar. Sci. 1990, 1-18. [CrossRef] 
29. Michonneau, F.; Helena Borrero-Perez, G.; Honey, M.; Rahim Kamarudin, K.; Kerr, A.M.; Kim, S.; Antonette, M.M.; Miller, A.; Adrián, O.J.; Olavides, R.D.; et al. The littoral sea cucumbers (Echinodermata: Holothuroidea) of Guam re-assessed-a diversity curve that still does not asymptote. Cah. Biol. Mar. 2013, 54, 531-540.

30. Bakus, G.J. Chemical defense mechanisms on the Great Barrier Reef, Australia. Science 1981, 211, $497-499$. [CrossRef]

31. Honey-Escandón, M.; Arreguín-Espinosa, R.; Solís-Marín, F.A.; Samyn, Y. Biological and taxonomic perspective of triterpenoid glycosides of sea cucumbers of the family Holothuriidae (Echinodermata, Holothuroidea). Comp. Biochem. Physiol. Part B 2015, 180, 16-39. [CrossRef]

32. Kerr, A.M.; Kim, J. Phylogeny of Holothuroidea (Echinodermata) inferred from morphology. Zool. J. Linn. Soc. 2001, 133, 63-81. [CrossRef]

33. Kalinin, V.I. System-theoretical (Holistic) approach to the modelling of structural-functional relationships of biomolecules and their evolution: An example of triterpene glycosides from sea cucumbers (Echinodermata, Holothurioidea). J. Biol. 2000, 206, 151-168. [CrossRef]

34. Kamyab, E.; Kellermann, M.Y.; Kunzmann, A.; Schupp, P.J. Chemical Biodiversity and Bioactivities of Saponins in Echinodermata with an Emphasis on Sea Cucumbers (Holothuroidea). In YOUMARES 9-The Oceans: Our Research, Our Future; Springer International Publishing: Cham, Switzerland, 2020; pp. 121-157.

35. Bordbar, S.; Anwar, F.; Saari, N. High-value components and bioactives from sea cucumbers for functional foods-A review. Mar. Drugs 2011, 9, 1761-1805. [CrossRef]

36. Datta, D.; Nath Talapatra, S.; Swarnakar, S. Bioactive compounds from marine invertebrates for potential medicines-An overview. Int. Lett. Nat. Sci. 2015, 7, 42-61. [CrossRef]

37. Soliman, Y.A.; Ibrahim, A.M.; Tadros, H.R.Z.; Abou-Taleb, E.A.; Moustafa, A.H.; Hamed, M.A. Antifouling and antibacterial activities of marine bioactive compounds extracted from some Red Sea sea cucumber. Int. J. Contemp. Appl. Sci. 2016, 3, 83-103.

38. Yuan, W.H.; Yi, Y.H.; Tang, H.F.; Liu, B.S.; Wang, Z.L.; Sun, G.Q.; Zhang, W.; Li, L.; Sun, P. Antifungal triterpene glycosides from the sea cucumber Bohadschia marmorata. Planta Med. 2009, 75, 168-173. [CrossRef]

39. Adibpour, N.; Nasr, F.; Nematpour, F.; Shakouri, A.; Ameri, A. Antibacterial and antifungal activity of Holothuria leucospilota isolated from Persian Gulf and Oman Sea. Jundishapur J. Microbiol. 2014, 7, 1-4. [CrossRef]

40. Kamyab, E.; Goebeler, N.; Kellermann, M.Y.; Rohde, S.; Reverter, M.; Striebel, M.; Schupp, P.J. Anti-Fouling Effects of Saponin-Containing Crude Extracts from Tropical Indo-Pacific Sea Cucumbers. Mar. Drugs 2020, 18, 181. [CrossRef] [PubMed]

41. Kalinin, V.I.; Aminin, D.L.; Avilov, S.A.; Silchenko, A.S.; Stonik, V.A. Triterpene glycosides from sea cucucmbers (holothurioidea, echinodermata). Biological activities and functions. In Studies in Natural Products Chemistry; Atta-ur-Rahman, Ed.; Elsevier: Oxford, UK, 2008; Volume 35, pp. 135-196.

42. Van Dyck, S.; Gerbaux, P.; Flammang, P. Qualitative and quantitative saponin contents in five sea cucumbers from the Indian ocean. Mar. Drugs 2010, 8, 173-189. [CrossRef] [PubMed]

43. Kalinin, V.I.; Silchenko, A.S.; Avilov, S.A.; Stonik, V.A.; Smirnov, A.V. Sea cucumbers triterpene glycosides, the recent progress in structural elucidation and chemotaxonomy. Phytochem. Rev. 2005, 4, 221-236. [CrossRef]

44. Wen, J.; Hu, C.; Zhang, L.; Fan, S. Genetic identification of global commercial sea cucumber species on the basis of mitochondrial DNA sequences. Food Control 2011, 22, 72-77. [CrossRef]

45. Kamarudin, K.R.; Hashim, R.; Usup, G. Phylogeny of sea cucumber (Echinodermata: Holothuroidea) as inferred from 16s mitochondrial rRNA gene sequences. Sains Malays. 2010, 39, 209-218.

46. Miller, A.K.; Kerr, A.M.; Paulay, G.; Reich, M.; Wilson, N.G.; Carvajal, J.I.; Rouse, G.W. Molecular phylogeny of extant Holothuroidea (Echinodermata). Mol. Phylogenet. Evol. 2017, 111, 110-131. [CrossRef]

47. Clarkson, C.; Maharaj, V.J.; Crouch, N.R.; Grace, O.M.; Pillay, P.; Matsabisa, M.G.; Bhagwandin, N.; Smith, P.J.; Folb, P.I. In vitro antiplasmodial activity of medicinal plants native to or naturalised in South Africa. J. Ethnopharmacol. 2004, 92, 177-191. [CrossRef] [PubMed]

48. Hamidi, M.; Jovanova, B.; Panovska, T. Toxicological evaluation of the plant products using Brine Shrimp (Artemia salina L.) model. Maced. Pharm. Bull. 2014, 60, 9-18. [CrossRef] 
49. Gelani, C.D.; Uy, M.M. Cytotoxicity to Artemia salina L. of marine sponge extracts from Surigao del Norte, Philippines. Bull. Env. Pharm. Life Sci. 2016, 5, 14-18.

50. Kitagawa, I.; Kobayashi, M.; Hori, M.; Kyogoku, Y. Marine Natural Producs. XVIII. Four lanostane- type triterpene oligoglycosides, bivittosides $\mathrm{A}, \mathrm{B}, \mathrm{C}$, and D from the Okinawan sea cucumber Bohadschia bivittata (Mitsukuri). Chem. Pharm. Bull. 1989, 37, 61-67. [CrossRef]

51. Lakshmi, V.; Saxena, A.; Pandey, K.; Raina, D.; Srivastava, M.N.; Khan, Z.K.; Jain, P.; Gupta, G.; Dhar, J.D. Isolation of Bivittoside D from Sea Cucumber and Activity Thereof. WO 2005/063789 A1, 14 July 2005. Available online: https://patents.google.com/patent/WO2005063789A1/en (accessed on 14 July 2005).

52. Kropp, R.K. Responses of Five Holothurian Species to Attacks by a Predatory Gastropod, Tonna Perdix; Pacific Science, University of Hawaii Press: Honolulu, HI, USA, 1982; Volume 36.

53. Chao, S.; Wu, S. Response of the sea cucumber Holothuria cinerascens to the predatory gastropod Tonna perdix. Platax 2015, 12, 81-88.

54. Van Dyck, S.; Caulier, G.; Todesco, M.; Gerbaux, P.; Fournier, I.; Wisztorski, M.; Flammang, P. The triterpene glycosides of Holothuria forskali: Usefulness and efficiency as a chemical defense mechanism against predatory fish. J. Exp. Biol. 2011, 214, 1347-1356. [CrossRef] [PubMed]

55. Purcell, S.W.; Samyn, Y.; Conand, C. Commercially Important Sea Cucumbers of the World; No 6; Food and Agriculture Organization of the United Nations: Rome, Italy, 2012; p. 150. ISBN 9789251067192.

56. Bahrami, Y.; Zhang, W.; Franco, C. Discovery of novel saponins from the viscera of the sea cucumber Holothuria lessoni. Mar. Drugs 2014, 12, 2633-2667. [CrossRef]

57. Clark, H.L. The Echinoderm Fauna of Torres Strait: Its Composition and Its Origin; No. 214; Department of Marine Biology of the Carnegie Institute: Washington, DC, USA, 1921.

58. Althunibat, O.; Ridzwan, B.; Taher, M.; Daud, J.; Jauhari Arief Ichwan, S.; Qaralleh, H. Antioxidant and cytotoxic properties of two sea cucumbers, Holothuria edulis Lesson and Stichopus horrens Selenka. Acta Biol. Hung. 2013, 64, 10-20. [CrossRef]

59. Bakus, G.J. Defensive mechanisms and ecology of some tropical holothurians. Mar. Biol. 1968, 2, $23-32$. [CrossRef]

60. Farouk, A.E.A.; Ghouse, F.A.H.; Ridzwan, B.H. New bacterial species isolated from Malaysian sea cucumbers with optimized secreted antibacterial activity. Am. J. Biochem. Biotechnol. 2007, 3, 60-65. [CrossRef]

61. Borrero-Pérez, G.H.; Gómez-Zurita, J.; González-Wangüemert, M.; Marcos, C.; Pérez-Ruzafa, A. Molecular systematics of the genus Holothuria in the Mediterranean and Northeastern Atlantic and a molecular clock for the diversification of the Holothuriidae (Echinodermata: Holothuroidea). Mol. Phylogenet. Evol. 2010, 57, 899-906. [CrossRef] [PubMed]

62. Kim, S.W.; Kerr, A.M.; Paulay, G. Colour, confusion, and crossing: Resolution of species problems in Bohadschia (Echinodermata: Holothuroidea). Zool. J. Linn. Soc. 2013, 168, 81-97. [CrossRef]

63. Kuznetsova, T.A.; Anisimov, M.M.; Popov, A.M.; Baranova, S.I.; Afiyatullov, S.S.; Kapustina, I.I.; Antonov, A.S.; Elyakov, G.B. A comparative study in vitro of physiological activity of triterpene glycosides of marine invertebrates of echinoderm type. Comp. Biochem. Physiol. Part C Comp. 1982, 73, 41-43. [CrossRef]

64. Lakshmi, V.; Srivastava, S.; Mishra, S.K.; Shukla, P.K. Antifungal activity of bivittoside-D from Bohadschia vitiensis (Semper). Nat. Prod. Res. 2012, 26, 913-918. [CrossRef] [PubMed]

65. Lakshmi, V.; Kumar Agarwal, S.; Ali Mahdi, A.; Saxena, A. Chemistry and biology of sea cucumbers. Nat. Prod. Indian J. 2014, 10, 102-112.

66. Hamel, J.F.; Mercier, A. Cuvierian tubules in tropical holothurians: Usefulness and efficiency as a defence mechanism. Mar. Freshw. Behav. Physiol. 2000, 33, 115-139. [CrossRef]

67. Bakus, G.J.; Targett, N.M.; Schulte, B. Chemical ecology of marine organisms: An overview. J. Chem. Ecol. 1986, 12, 951-987. [CrossRef]

68. Yamanouchi, T. On the Poinsiounous Substance contained in Holothurians. Public Seto Mar. Biol. Lab. 1955, 4, 183-203. [CrossRef]

69. Stonik, V.A.; Mal'tsev, I.I.; Elyakov, G.B. The structure of Thelenotosides A and B from the holothurian Thelenota ananas. Chem. Nat. Compd. 1982, 18, 590-593. [CrossRef]

70. Maier, M.S. Biological activities of sulfated glycosides from echinoderms. Stud. Nat. Prod. Chem. 2008, 35, 311-354. [CrossRef]

71. Pangestuti, R.; Arifin, Z. Medicinal and health benefit effects of functional sea cucumbers. J. Tradit. Complement. Med. 2018, 8, 341-351. [CrossRef] [PubMed] 
72. Kitagawa, I.; Kobayashi, M.; Hori, M.; Kyogoku, Y. Structures of four new triterpenoidal oligoglycosides, Bivittoside A, B, C, and D, from the sea cucumber Bohadschia bivittata MITSUKURI. Chem. Pharm. Bull. 1981, 29, 282-285. [CrossRef]

73. van Dyck, S.; Flammang, P.; Meriaux, C.; Bonnel, D.; Salzet, M.; Fournier, I.; Wisztorski, M. Localization of secondary metabolites in marine invertebrates: Contribution of MALDI MSI for the study of saponins in Cuvierian tubules of H. forskali. PLoS ONE 2010, 5, e13923. [CrossRef] [PubMed]

74. Mondol, M.A.M.; Shin, H.J.; Rahman, M.A.; Islam, M.T. Sea cucumber glycosides: Chemical structures, producing species and important biological properties. Mar. Drugs 2017, 15, 317. [CrossRef]

75. Bourjon, P. Field observations on the regeneration in Synapta maculata (Holothuroidea: Synaptidae). SPC Beche-De-Mer Inf. Bull. 2017, 37, 105-106.

76. Emson, R.H.; Wilkie, I.C. Fission and Autotomy in Echinoderms; Aberdeen University Press: Aberdeen, UK, 1980; ISBN 00802573219780080257327.

77. Smiley, S.; McEuen, F.S.; Chaffee, C.; Krishnan, S. Echinodermata: Holothuroidea. In Reproduction of Marine Invertebrates; Giese, A., Pearse, J., Pearse, V., Eds.; Boxwood Press: Pacific Grove, CA, USA, 1991; pp. 663-750.

78. Ponomarenko, L.P.; Kalinovsky, A.I.; Moiseenko, O.P.; Stonik, V.A. Free sterols from the holothurians Synapta maculata, Cladolabes bifurcatus and Cucumaria sp. Comp. Biochem. Physiol. B Biochem. Mol. Biol. 2001, 128, 53-62. [CrossRef]

79. Flammang, P.; Conand, C. Functional morphology of the tentacles in the apodid holothuroid Synapta maculata. In Echinoderms: München; Taylor and Francis Group: London, UK, 2004; pp. 327-333. ISBN 0415364817.

80. Brandt, J.F. Echinodermata Ordo Holothurina. Prodromus Descriptionis Animalium ab H. Mertensio in Orbis Terrarum Circumnavigatione Observatorum. Fascic, I., Ed.; 1835, pp. 42-62. Available online: https: //books.google.com/books?id=9-KK6BsniXcC (accessed on 15 October 2020).

81. Jaeger, G.F. De Holothuriis. Gessnerianis, Turici. 1833. Available online: https://biodiversitylibrary.org/page/ 10588969 (accessed on 15 October 2020).

82. Bronn, H.G. Die Klassen und Ordnungen der Strahlenthiere (Actinozoa) wissenschaftlich dargestellt. In Die Klassen und Ordnungen des Thier-Reichs, wissenschaftlich dargestellt in Wort und Bild. C.F.; Winter'sche Verlagshandlung: Heidelberg, Germany, 1860; 434p.

83. Linnaeus, CSystema Naturae per Regna Tria Naturae: Secundum Classes, Ordines, Genera, Species, Cum Characteribus, Differentiis, Synonymis, Locis. Ed. 12.1, Regnum Animale. 1 \& 2. Holmiae, Laurentii Salvii. 1767, Holmiae [Stockholm], Laurentii Salvii. pp. 1-532 [1766]; pp. 533-1327 [1767]. Available online: http://www.biodiversitylibrary.org/item/83650\#5 (accessed on 15 October 2020).

84. Chamisso Adelbertus de \& Eysenhardt Carolus Guilelmus. De animalibus Quibusdam e Classe Vermium Linneana, in Circumnavigatione Terrae, Auspicante Comite, N. Romanoff, Duce Ottone di Kotzebue, annis 1815-1818 Peracta, Observatis Fasciculus Secundus, Reliquos Vermes Continens. Nova Acta Physico-Medica Academiae Cesareae Leopoldino-Carolinae 10: 343-373, Plates 24 to 33. 1821. Available online: http://biodiversitylibrary.org/page/37020829 (accessed on 15 October 2020).

85. Cutignano, A.; Nuzzo, G.; Ianora, A.; Luongo, E.; Romano, G.; Gallo, C.; Sansone, C.; Aprea, S.; Mancini, F.; D'Oro, U.; et al. Development and application of a novel SPE-method for bioassay-guided fractionation of marine extracts. Mar. Drugs 2015, 13, 5736-5749. [CrossRef]

86. Rohde, S.; Schupp, P.J. Allocation of chemical and structural defenses in the sponge Melophlus sarasinorum. J. Exp. Mar. Biol. Ecol. 2011, 399, 76-83. [CrossRef]

87. Amesbury, S.S.; Myers, R.F. Guide to the Coastal Resources of Guam; The corals University of Guam Press: Mangilao, Guam, Philippines, 1982; Volume 1, pp. 1-141.

88. Pennings, S.C.; Pablo, S.R.; Paul, V.J.; Emmett Duffy, J. Effects of sponge secondary metabolites in different diets on feeding by three groups of consumers. J. Exp. Mar. Biol. Ecol. 1994, 180, 137-149. [CrossRef]

89. Slattery, M.; Paul, V.J. Indirect effects of bleaching on predator deterrence in the tropical Pacific soft coral Sinularia maxima. Mar. Ecol. Prog. Ser. 2008, 354, 169-179. [CrossRef]

90. Slattery, M.; Avila, C.; Starmer, J.; Paul, V.J. A sequestered soft coral diterpene in the aeolid nudibranch Phyllodesrnium guamensis Avila, Ballesteros, Slattery, Starmer and Paul. J. Exp. Mar. Biol. Ecol. 1998, 226, 33-49. [CrossRef]

91. Rohde, S.; Gochfeld, D.J.; Ankisetty, S.; Avula, B.; Schupp, P.J.; Slattery, M. Spatial variability in secondary metabolites of the Indo-Pacific sponge Stylissa massa. J. Chem. Ecol. 2012, 38, 463-475. [CrossRef] [PubMed] 
92. Cronin, G.; Hay, M.E. Susceptibility to herbivores depends on recent history of both the plant and animal. Ecology 1996, 77, 1531-1543. [CrossRef]

93. Helber, S.B.; de Voogd, N.J.; Muhando, C.A.; Rohde, S.; Schupp, P.J. Anti-predatory effects of organic extracts of 10 common reef sponges from Zanzibar. Hydrobiologia 2017, 790, 247-258. [CrossRef]

94. Pawlik, J.R.; Chanas, B.; Toonen, R.J.; Fenical, W. Defenses of Caribbean sponges against predatory reef fish. I. Chemical deterrency. Mar. Ecol. Prog. Ser. 1995, 127, 183-194. [CrossRef]

95. Carballo, J.L.; Hernández-Inda, Z.L.; Pérez, P.; García-Grávalos, M.D. A comparison between two brine shrimp assays to detect in vitro cytotoxicity in marine natural products. Bmc Biotechnol. 2002, 2, 1-5. [CrossRef]

96. Migliore, L.; Civitareale, C.; Brambilla, G.; Dojmi di Delupis, G. Toxicity of several important agricultural antibiotics to Artemia. Water Res. 1997, 31, 1801-1806. [CrossRef]

97. Meyer, B.; Ferrigni, N.; Putnam, J.; Jacobsen, L.; Nichols, D.; McLaughlin, J. Brine shrimp: A convenient general bioassay for active plant constituents. Planta Med. 1982, 45, 31-34. [CrossRef]

98. Zaehner, H.; Maas, W.K. Biologie der Antibiotica; Springer: Berlin/Heidelberg, Germany; New York, NY, USA, 1965; Volume 53, ISBN 9788578110796.

99. Drews, G. Mikrobiologisches Praktikum; Springer: Berlin/Heidelberg, Germany; New York, NY, USA, 1976; ISBN 9783642251504.

100. Li, J.; Cao, J.; Wang, X.; Liu, N.; Wang, W.; Luo, Y. Acinetobacter pittii, an emerging new multi-drug resistant fish pathogen isolated from diseased blunt snout bream (Megalobrama amblycephala Yih) in China. Appl. Microbiol. Biotechnol. 2017, 101, 6459-6471. [CrossRef] [PubMed]

101. Larcher, R.; Pantel, A.; Arnaud, E.; Sotto, A.; Lavigne, J.-P. First report of cavitary pneumonia due to community- acquired Acinetobacter pittii, study of virulence and overview of pathogenesis and treatment. BMC Infect. Dis. 2005, 56, 893-898. [CrossRef]

102. Denner, E.B.M.; Smith, G.W.; Busse, H.-J.; Schumann, P.; Narzt, T.; Polson, S.W. Aurantimonas coralicidagen. nov., sp. nov., the causative agent of white plague type II on Caribbean scleractinian corals. Int. J. Syst. Evol. Microbiol. 2003, 53, 1115-1122. [CrossRef] [PubMed]

103. Kushmaro, A.; Banin, E.; Loya, Y.; Stackebrandt, E.; Rosenberg, E. Vibrio shiloi sp. nov., the causative agent of bleaching of the coral Oculina patagonica. Int. J. Syst. Evol. Microbiol. 2001, 51, 1383-1388. [CrossRef] [PubMed]

104. Ben-Haim, Y.; Banim, E.; Kushmaro, A.; Loya, Y.; Rosenberg, E. Inhibition of photosynthesis and bleaching of zooxanthellae by the coral pathogen Vibrio shiloi. Environ. Microbiol. 1999, 1, 223-229. [CrossRef] [PubMed]

105. Ben-Haim, Y.; Rosenberg, E. A novel Vibrio sp. pathogen of the coral Pocillopora damicornis. Mar. Biol. 2002, 141, 47-55. [CrossRef]

106. Ben-Haim, Y.; Thompson, F.L.; Thompson, C.C.; Cnockaert, M.C.; Hoste, B.; Swings, J. Vibrio coralliilyticus sp. nov., a temperature-dependent pathogen of the coral Pocillopora damicornis. Int. J. Syst. Evol. Microbiol. 2003, 53, 309-315. [CrossRef]

107. Ushijima, B.; Videau, P.; Burger, A.H.; Shore-Maggio, A.; Runyon, C.M.; Sudek, M. Vibrio coralliilyticus strain OCN008 is an etiological agent of acute montipora white syndrome. Appl. Environ. Microbiol. 2014, 80, 2102-2109. [CrossRef] [PubMed]

108. Costa Pellegrino, F.L.P.; Vieira, V.V.; Pereira Baio, P.V.; dos Santos, R.M.; dos Santos, A.L.A.; Gomes de Barros Santos, N.; Gaudie Ley Meohas, M.M.; Santos, R.T.; de Souza, T.C.; da Silva Dias, R.C.; et al. Acinetobacter soli as a Cause of Bloodstream Infection in a Neonatal Intensive Care Unit. J. Clin. Microbiol. 2011, 49, 2283-2285. [CrossRef]

109. Kitamura, Y.; Sawabe, E.; Ohkusu, K.; Tojo, N.; Tohda, T. First Report of Sepsis Caused by Rhodococcus corynebacterioides in a Patient with Myelodysplastic Syndrome. J. Clin. Microbiol. 2011, 1089-1091. [CrossRef]

110. Lotte, L.; Sindt, A.; Ruimy, R.; Neri, D.; Lotte, R.; Weiss, N.; Vassallo, M. Description of the First Case of Catheter-Related Bloodstream Infection Due To Pantoea eucrina in a Cancer Patient. SN Compr. Clin. Med. 2018, 4. [CrossRef]

111. Zhou, G.; Luo, X.; Tang, Y.; Zhang, L.; Yang, Q.; Qiu, Y.; Fang, C. Kocuria flava sp. nov. and Kocuria turfanensis sp. nov., airborne actinobacteria isolated from Xinjiang, China. Int. J. Syst. Evol. Microbiol. 2008, 58, 1304-1307. [CrossRef]

112. Hiai, S.; Oura, H.; Nakajima, N. Color Reaction of Some Sapogenins and saponins with vanillin and sulfur1c acid. Planta Med. 1976, 29, 116-122. [CrossRef] [PubMed] 
113. Ozupek, N.M.; Cavas, L. Triterpene glycosides associated antifouling activity from Holothuria tubulosa and H. polii. Reg. Stud. Mar. Sci. 2017, 13, 32-41. [CrossRef]

114. Robertson, J.; Russel, R.; Preisler, H.; Savin, N. Bioassays with Arthropods, 2nd ed.; CRC Press: Boca Raton, FL, USA, 2007.

115. Miller, I. Ecotoxicological Tests of UV Filters and Related Compounds on Scleractinian Corals of Different Life Stages on Guam. Master's Thesis, University of Oldenburg, Oldenburg, Germany, 2020.

116. Savi, M.K.; Mangamana, E.T.; Deguenon, J.M.; Hounmenou, C.G.; Kakaï, R.G. Determination of Lethal Concentrations Using an R Software Function Integrating the Abbott Correction. J. Agric. Sci. Technol. A 2017, 7, 25-30. [CrossRef]

Sample Availability: Samples of the compounds bivittoside $C, D$ and butanol fractions are available from the authors.

Publisher's Note: MDPI stays neutral with regard to jurisdictional claims in published maps and institutional affiliations.

(C) 2020 by the authors. Licensee MDPI, Basel, Switzerland. This article is an open access article distributed under the terms and conditions of the Creative Commons Attribution (CC BY) license (http://creativecommons.org/licenses/by/4.0/). 